\title{
Article \\ Engine Vibration Data Increases Prognosis Accuracy on Emission Loads: A Novel Statistical Regressions Algorithm Approach for Vibration Analysis in Time Domain
}

\author{
Tadas Žvirblis ${ }^{1}$, Darius Vainorius ${ }^{2}$, Jonas Matijošius ${ }^{2, *} \mathbb{C}$, Kristina Kilikevičienè ${ }^{2}$, Alfredas Rimkus ${ }^{3}$, \\ Ákos Bereczky ${ }^{4}$, Kristóf Lukács ${ }^{4}$ and Artūras Kilikevičius ${ }^{2}$ (D) \\ 1 Department of Mechanical and Material Engineering, Vilnius Gediminas Technical University, \\ LT-03224 Vilnius, Lithuania; tadas.zvirblis@vilniustech.lt \\ 2 Institute of Mechanical Science, Vilnius Gediminas Technical University, LT-03224 Vilnius, Lithuania; \\ darius.vainorius@vilniustech.lt (D.V.); kristina.kilikeviciene@vilniustech.lt (K.K.); \\ arturas.kilikevicius@vilniustech.lt (A.K.) \\ 3 Department of Automobile Engineering, Vilnius Gediminas Technical University, LT-03224 Vilnius, Lithuania; \\ alfredas.rimkus@vilniustech.lt \\ 4 Department of Energy Engineering, Budapest University of Technology and Economics, \\ H-1111 Budapest, Hungary; bereczky@energia.bme.hu (Á.B.); lukacs@energia.bme.hu (K.L.) \\ * Correspondence: jonas.matijosius@vilniustech.lt; Tel.: +370-68404169
}

Citation: Žvirblis, T.; Vainorius, D.; Matijošius, J.; Kilikevičienè, K.; Rimkus, A.; Bereczky, Á.; Lukács, K.; Kilikevičius, A. Engine Vibration Data Increases Prognosis Accuracy on Emission Loads: A Novel Statistical Regressions Algorithm Approach for Vibration Analysis in Time Domain. Symmetry 2021, 13, 1234. https:// doi.org/10.3390/sym13071234

Academic Editors: Jan Awrejcewicz and Basil Papadopoulos

Received: 8 May 2021

Accepted: 2 July 2021

Published: 9 July 2021

Publisher's Note: MDPI stays neutral with regard to jurisdictional claims in published maps and institutional affiliations.

Copyright: (C) 2021 by the authors Licensee MDPI, Basel, Switzerland. This article is an open access article distributed under the terms and conditions of the Creative Commons Attribution (CC BY) license (https:// creativecommons.org/licenses/by/ $4.0 /)$.
Abstract: Statistical regression models have rarely been used for engine exhaust emission parameters. This paper presents a three-step statistical analysis algorithm, which shows increased prediction accuracy when using vibration and sound pressure data as a covariate variable in the exhaust emission prediction model. The first step evaluates the best time domain statistic and the point of collection of engine data. The univariate linear regression model revealed that non-negative time domain statistics are the best predictors. Also, only one statistic evaluated in this study was a statistically significant predictor for all 11 exhaust parameters. The ecological and energy parameters of the engine were analyzed by statistical analysis. The symmetry of the methods was applied in the analysis both in terms of fuel type and in terms of adjustable engine parameters. A three-step statistical analysis algorithm with symmetric statistical regression analysis was used. Fixed engine parameters were evaluated in the second algorithm step. ANOVA revealed that engine power was a strong predictor for fuel mass flow, $\mathrm{CO}, \mathrm{CO}_{2}, \mathrm{NO}_{\mathrm{x}}, \mathrm{THC}, \mathrm{CO}_{\text {Sick }}, \mathrm{O}_{2}$, air mass flow, $\mathrm{t}_{\text {exhaust, whereas }}$ type of fuel was only a predictor of $t_{\text {air }}$ and $t_{\text {fuel }}$. Injection timing did not allow predicting any exhaust parameters. In the third step, the best fixed engine parameter and the best time domain statistic was used as a model covariate in ANCOVA model. ANCOVA model showed increased prediction accuracy in all 11 exhausted emission parameters. Moreover, vibration covariate was found to increase model accuracy under higher engine power $(12 \mathrm{~kW}$ and $20 \mathrm{~kW})$ and using several types of fuels (HVO30, HVO50, SME30, and SME50). Vibration characteristics of diesel engines running on alternative fuels show reliable relationships with engine performance characteristics, including amounts and characteristics of exhaust emissions. Thus, the results received can be used to develop a reliable and inexpensive method to evaluate the impact of various alternative fuel blends on important parameters of diesel engines.

Keywords: biodiesel; exhausted emission; statistical regression analysis; linear regression models

\section{Introduction}

Vehicle emission indicators have become increasingly more stringent in pursuit of environmental benefits [1]. Decarbonization programs aimed at the use of clean, low-carbon fuels in vehicles have been used to this end. Ambitious targets set to reduce concentrations of hazardous compounds in exhaust gases have recently been supplemented with strict 
requirements to reduce particulate matter concentrations and volumes [2], which have already been transposed into the legal framework (Euro 6 standard requirements) [3].

Thus attempts have been made to also limit harmfulness of exhaust gases through the use of alternative fuels [4]. These can be ethanol-based fuels when improvements in environmental and operational processes have been observed at low concentrations of ethanol additive. Increasing the concentration of ethanol additive in fuel blends results in an engine running loud and deterioration in the quality of its performance. Various exhaust gas regulation (EGR) scenarios have been used to fix this problem, when increasing the EGR rate has led to a reduction in thermal efficiency [5]. Another method is the supply of hydrogen, but supplying it with ethanol and hydrogen simultaneously led to increased soot concentration $[6,7]$. The use of blends of oxygenates and diesel is an effective method to reduce soot concentrations, as it allows to reduce harmfulness of exhaust components [8] (except for $\mathrm{NO}_{\mathrm{x}}$, the concentration of which increases at higher temperatures [9]). These can be various blends of dibutyl maleate and diesel [10], and of biodiesel (starting with esters of palm oil [11], fat [12], rapeseed oil [13] and diesel.

Another option is using blends of hydrotreated vegetable oils (HVO) with diesel and soybean oil methyl ester (SME) with diesel. Properties of HVO blends with diesel not only improve environmental engine indicators, but also allow achieving better performance characteristics thereof $[14,15]$, especially when optimizing the principal fuel injection timing [16]. Adding Ferrocene nanoparticles to diesel-HVO (7\% HVO in diesel) blends can reduce $\mathrm{NO}_{\mathrm{x}}$ concentrations by $30 \%$ [17], while the use of various EGR strategies leads to an increase in THC and CO concentrations at high EGR mode [18].

When it comes to soybean oil methyl ester blends with diesel, environmental effect of the use thereof has also been observed, at the same time emphasizing the stability and taring of such blends [19]. Viscosity of soybean oil methyl ester, which is 10 times higher than that of diesel, is another notable problem, thus its application is highly limited especially at ambient temperatures below zero [20].

The review of literature offers solutions for environmental engine problems through the use of biodiesels mentioned in various sources. On the other hand, the use of such fuel results in lower engine vibrations, especially when it comes to the dual fuel engine [21]. The use of various additives (such as DTiCuN100 (Diesel $+50 \mathrm{ppm} \mathrm{\textrm {TiO } _ { 2 }}$ (Titanium (IV) dioxide $\left.\left(\mathrm{TiO}_{2}\right)\right)+50 \mathrm{ppm} \mathrm{Cu}\left(\mathrm{NO}_{3}\right)_{2}$ (copper (II) nitrate $\left(\mathrm{Cu}\left(\mathrm{NO}_{3}\right)_{2}\right)$ and DTiCeA100 (Diesel + $50 \mathrm{ppm} \mathrm{TiO} \mathrm{O}_{2}+50 \mathrm{ppm} \mathrm{Ce}\left(\mathrm{CH}_{3} \mathrm{CO}_{2}\right)_{3} \cdot \mathrm{H}_{2} \mathrm{O}$ (cerium(III) acetate hydrate)) allowed reducing the level of engine's vibration and sound in all modes of operation of the engine [22]. This allows concluding that the level of sound pressure and vibrations can be lower using various fuel additives compared to standard EN590 diesel. This has been observed when using waste cooking oil (WCO) blends with diesel, and vibrations have further decreased having added hydrogen [23]. Research with hydrogen and diesel blends also confirm this trend, but vibrations can be emphasized to increase proportionally when increasing engine load [24]. However, such research of vibrations is more targeted at identifying vibration levels manifesting when using different biofuels-Calophyllum inophyllum biofuel blends with diesel [25], three-component diesel—sunflower oil—HHO, diesel—canola oil -HHO and diesel—corn oil-HHO blends [26].

Favorable prediction results were shown using linear and non-linear statistical models for noise and vibration characteristic predictions using different fuel blends (low sulphur diesel, sunflower, canola, corn biodiesels) at different engine speeds [27].

Another statistical approach was used to evaluate influence of various biodiesel blends at different engine speeds seeking to identify the fuel blends with the minimal vibration [28]. Using two-way ANOVA statistical model there was observed that vibration values significantly depend on biodiesel blends and engine speed.

Moreover, advanced artificial neural network (ANN) modelling was used to predict noise and vibration level of the engine using various fuel blends at different engine speeds [29]. Nevertheless, authors additionally presented a wide analysis of engine exhausted emissions they did not apply artificial neural network modelling for it. 
Papers with predictions of engine exhaust emissions using ANN are very sparse. Cay et al. [30] showed that ANN with input data such as fuel type, engine speed, torque, fuel flow, carbon monoxide, unburned hydrocarbon, break specific fuel consumption and airfuel ratio can be very useful and accurate in CO, THC, BSFC and AFR values predictions. Unfortunately, engine vibration was not included as input data.

One more comprehensive study for modeling of performance, emission, and vibration of a compressed ignition engine using ANN technique was performed by Hosseini et al. (2020) [31]. Even 12 parameters in input layer were used in ANN model for predicting another 12 parameters in output layer. However, as in previous study engine vibration data was not included in the input layer.

Literature review can imply that building a prediction models for exhausted emission of ignition engines through statistical point of view is still challenging. Although, there are developed several models which can be used for exhausted emission parameters predicting but these models require a lot of input variables which can cause data gathering issues.

In this paper, three-step statistical analysis algorithm is presented to develop optimal prognostic model for 11 exhausted emission parameters. Vibration and sound pressure data in combination with stationary engine parameters such as engine power, fuel type and injection timing were used as prediction model input parameters.

The objectives of this study are the following: (1) to investigate the prognostic impact of vibrational and sound pressure data on engine emission parameters; (2) to evaluate if vibration and sound pressure data together with fixed engine parameters, i.e., power, type of fuel and fuel injection timing can improve prediction accuracy; (3) to investigate the best prediction model for exhausted emission parameters dependent from the fixed engine parameters and vibration and sound pressure data.

The rest of the paper is organized as follows: methodology and data description are described in Section 2; in Section 3, the results of the investigated statistical analysis for emission prediction are presented, and the conclusions close the article in Section 4.

During statistical analysis, we have analyzed one of the eleven engine emission parameter. In such way, we have symmetrically repeated statistical analysis for the rest of 10 engine emission parameters. So, we have proposed three-step statistical analysis algorithm with symmetrical statistical regression analysis. Also, LRM, ANOVA and ANCOVA requires normally distributed (i.e., symmetrical) quantitative data sample. We have checked this assumption with Kolmogorov-Smirnov criteria and found that data satisfies this assumption. Data normality confirmation is not the key to our analysis, so authors decided to not define this analysis.

\section{Methodology and Data Description}

\subsection{Exhausted Emission Parameters}

The investigations were elaborated on a naturally aspired, direct-injection 2.9 L IVECO AIFO Diesel engine provides the task of the machinery, which is driven by an M8B 160 generator. The engine set was made for generator purposes. Thus, it did not incorporate heat recovery. Therefore, a separate system had to be established for this purpose for the basic engine set. Exhaust gas analysis was performed using specialized measuring equipment, which was calibrated with a special gas before and after the tests. AVS 415 for FSN was used for particulate emission measurements. THC flame ionization detector, NOx chemiluminescence analyzer and $\mathrm{CO}$ (sick) and $\mathrm{CO} 2$ non-dispersive infrared detector and $\mathrm{O} 2$ para-magnetic were used to capture emissions of other gases. Table 1 summarizes instrumentation and their description, accuracy and measurement range used both for recording combustion characteristics and for emission tests, based on calculations the $\delta_{\mathrm{pi}, \mathrm{t}}=3.29 \%$. 
Table 1. Used instrumentation.

\begin{tabular}{|c|c|c|}
\hline Equipment/Device & Description Accuracy & Measurement Range \\
\hline Fuel consumption AVL-7131-12 & $\delta= \pm 0.23 \%$ & 0-100 kg/h; \\
\hline \multirow{2}{*}{\multicolumn{3}{|c|}{$\begin{array}{c}\text { Exhaust gas-analyzer system HORIBA } \\
\text { MEXA-8120 F }\end{array}$}} \\
\hline & & \\
\hline THC analyzer: FIA-22 (HORIBA) & $\pm 4.35 \%\left(\delta_{\mathrm{I}, \mathrm{s}}\right)$ & form $0-10$, up to $0-5000 \mathrm{ppm}$ \\
\hline $\mathrm{NO} / \mathrm{NO}_{\mathrm{x}}$ analyzer: CLA-53 & $\pm 4.42 \%\left(\delta_{\mathrm{I}, \mathrm{s}}\right)$ & form $0-10$, up to $0-5000 \mathrm{ppm}$ \\
\hline CO analyzer: URAS 10E & $<5 \%\left(\delta_{\mathrm{I}, \mathrm{s}}\right)$ & 0-200 and 0-1000 ppm \\
\hline $\mathrm{CO}_{2}$ analyzer: URAS $10 \mathrm{E}$ & $<5 \%\left(\delta_{\mathrm{I}, \mathrm{s}}\right)$ & $0-10 v / v \%$ \\
\hline $\mathrm{O}_{2}$ analyzer: SICK Maihak: S-710 & $<5 \%\left(\delta_{\mathrm{I}, \mathrm{s}}\right)$ & $0-5$ and $0-25 v / v \%$ \\
\hline CO analyzer: SICK Maihak: S-710 & $<5 \%\left(\delta_{\mathrm{I}, \mathrm{S}}\right)$ & $0-5$ and $0-50 v / v \%$ \\
\hline Piezo transducer Kistler KIAG 6005 & Linearity $\leq \pm 0.8$ (\% FSO $)$ & $0-500$ bar \\
\hline Charge amplifier Kistler 5018A 1000 & $\delta_{\mathrm{pi}}<0.01 \%$ & $\begin{array}{c}\geq \pm 100 \text { pC FS (max./typ.) } \%< \pm 1 /< \pm 0.5 \pm \\
10 \ldots \pm 999,000 \mathrm{pC}\end{array}$ \\
\hline $\begin{array}{l}\text { Crank angle speed encoder HENGSTLER RI } \\
\text { 32-0/1024.ER.14 ka }\end{array}$ & 1024 pulses/round & $\max .6000 \mathrm{rmp}$ \\
\hline DeltaOHM HD2101.1 & $\pm 0.1{ }^{\circ} \mathrm{C} ; 0.1 \% \mathrm{RH} \%$ & $\begin{array}{c}-50 \ldots+250^{\circ} \mathrm{C} \\
0 \ldots 100 \% \mathrm{RH}\end{array}$ \\
\hline
\end{tabular}

\subsection{Type of Fuel}

Four fuel blends and conventional diesel fuel was used in the research. Fuel blends consisted of conventional diesel fuel (D100) and hydrotreated vegetable oil (HVO100) or soybean oil methyl ester (SME100). Renewable biofuels accounted for $30 \%$ or $50 \%$ in the blends, and were marked as HVO30, HVO50, SME30 and SME50 in the article. All 4 biodiesel blends were volume-based. Physical and chemical properties of pure base fuels were analyzed in the laboratory and are presented in Table 2.

Table 2. Physical and chemical fuel properties.

\begin{tabular}{|c|c|c|c|c|c|c|}
\hline \multirow{2}{*}{ Properties } & \multirow{2}{*}{ Device } & \multirow{2}{*}{ Method } & \multirow{2}{*}{ Accuracy } & \multicolumn{3}{|c|}{ Fuel } \\
\hline & & & & Diesel 100 & HVO100 & SME100 \\
\hline Gross heating value, $\mathrm{MJ} / \mathrm{kg}$ & IKA C 5000 & \multirow{2}{*}{ DIN 51900-2 } & \multirow{2}{*}{$130 \mathrm{~J} / \mathrm{g}$} & 46.60 & 47.19 & 39.81 \\
\hline Lower heating value $L H V, \mathrm{MJ} / \mathrm{kg}$ & calorimeter & & & 42.86 & 43.63 & 37.29 \\
\hline $\mathrm{CFPP},{ }^{\circ} \mathrm{C}$ & FPP 5 Gs analyzer & EN 116 & $1^{\circ} \mathrm{C}$ & -37 & -44 & -4 \\
\hline Pour point, ${ }^{\circ} \mathrm{C}$ & CPP 5 Gs analyzer & ISO 3016 & $3^{\circ} \mathrm{C}$ & -42 & -50 & -6 \\
\hline Dynamic viscosity, $40^{\circ} \mathrm{C}, \mathrm{mPa} \times \mathrm{s}$ & \multirow{6}{*}{$\begin{array}{c}\text { Anton Paar SVM } \\
\text { 3000/G2 Stabinger } \\
\text { Viscometer }\end{array}$} & \multirow{6}{*}{ ASTM D7042 } & $0.1 \%$ & 1.745 & 2.198 & 3.657 \\
\hline Kinematic viscosity, $40^{\circ} \mathrm{C}, \mathrm{mm}^{2} / \mathrm{s}$ & & & $0.1 \%$ & 2.159 & 2.876 & 4.211 \\
\hline Density at $40^{\circ} \mathrm{C}, \mathrm{g} / \mathrm{mL}$ & & & \multirow[t]{3}{*}{$0.0002 \mathrm{~g} / \mathrm{cm}^{3}$} & 0.809 & 0.767 & 0.868 \\
\hline Dynamic viscosity, $15^{\circ} \mathrm{C}, \mathrm{mPa} \times \mathrm{s}$ & & & & 2.975 & 4.014 & 6.742 \\
\hline Kinematic viscosity, $15^{\circ} \mathrm{C}, \mathrm{mm}^{2} / \mathrm{s}$ & & & & 3.602 & 5.151 & 7.606 \\
\hline Density at $15^{\circ} \mathrm{C}, \mathrm{g} / \mathrm{mL}$ & & & \multirow[b]{2}{*}{$0.1 \%$} & 0.826 & 0.781 & 0.887 \\
\hline Oxidative stability, $\min$ & $\begin{array}{l}\text { PetroOXY analyzer } \\
\text { Aquamax KF }\end{array}$ & EN 16091 & & 48.56 & 120 & 18.45 \\
\hline Water content acc. $\mathrm{CF}, \%$ & $\begin{array}{l}\text { Coulometric } \\
\text { analyzer }\end{array}$ & ISO 12937 & $0.0003 \%$ & 0.0028 & 0.0021 & 0.0922 \\
\hline Lubricity, $\mu \mathrm{m} / 60^{\circ} \mathrm{C}$ & $\begin{array}{l}\text { WSD } \\
\text { FP93 5G2 }\end{array}$ & ISO 12156 & $63 \mu \mathrm{m}$ & 404 & 302 & 183 \\
\hline Flash point, ${ }^{\circ} \mathrm{C}$ & $\begin{array}{c}\text { Pensky-Martens } \\
\text { analyzer }\end{array}$ & ISO 2719 & $0.03^{\circ} \mathrm{C}$ & 67.8 & 87 & 90 \\
\hline \multirow{3}{*}{ Elemental composition, $\% \mathrm{wt}$} & \multirow[b]{4}{*}{$\begin{array}{l}\text { PetroSpec analyzer } \\
\text { TD-PPA-I }\end{array}$} & Combustion of samples in a catalytic & $\mathrm{H}$ & 13.5 & 15.3 & 11.12 \\
\hline & & tube, separation of combustion gases, & $\mathrm{C}$ & 86.5 & 84.7 & 78.08 \\
\hline & & $\begin{array}{l}\text { determination of components with a } \\
\text { thermal conductivity detector }\end{array}$ & $\mathrm{O}$ & 0 & 0 & 10.80 \\
\hline Cetane number & & ASTM D613 & $0.05 \%$ & 51 & 72 & 52 \\
\hline
\end{tabular}

\subsection{Experimental Engine}

The fuel tests were carried out on an IVECO AIFO 2.9 liter direct injection, natu-rally aspirated compression ignition. The engine drives an M8B 160 generator, and the energy produced was used in a multi-power stage water heating boiler. The main pa-rameters of the engine are shown in Table 3. During the test series, using the pre-injection adjuster alone is used to set the pre-ignition angle, no other modifications were made to the engine. The engine operated in any case with the basic settings for fossil diesel. 
Table 3. The main parameters of the tested engine.

\begin{tabular}{ccc}
\hline Parameter & & Unit \\
\hline Number of cylinders & 3 in line & - \\
Displacement & 2.9 & $\mathrm{dm}^{3}$ \\
Bore & 104 & $\mathrm{~mm}$ \\
Stroke & 115 & $\mathrm{~mm}$ \\
Compression ratio & $17: 1$ & - \\
Rated power & 24 & $\mathrm{~kW}$ \\
Speed & 1500 & $\mathrm{rpm}$ \\
\hline
\end{tabular}

\subsection{The Engine Testing System}

The test bench scheme is presented in Figure 1. The measurement system includes a number of static pressure and temperature sensors. Two piezo sensors are installed to measure the fast-changing pressures, one measuring the pressure in the combustion chamber and the other measuring the pressure in the high-pressure injection line. The sensors are connected to the data acquisition system after the charge amplifiers. The encoder on the crankshaft was used to trigger the measurements (1024 pulses/rev). 75 cycles were measured at each measurement point. The calibration of the system (pres-sure transducer, cables, charge amplifier and data acquisition system) before and after the tests (range 100 bar) and the accuracy was calculated.During the study. there were defined different starts of fuel injection timing, which were evaluated as crank angle degrees (CAD) before top dead center (BTDC) (5 CAD BTDC, 7.5 CAD BTDC, 10 CAD BTDC, 12.5 CAD BTDC, 15 CAD BTDC, and 17.5 CAD BTDC).

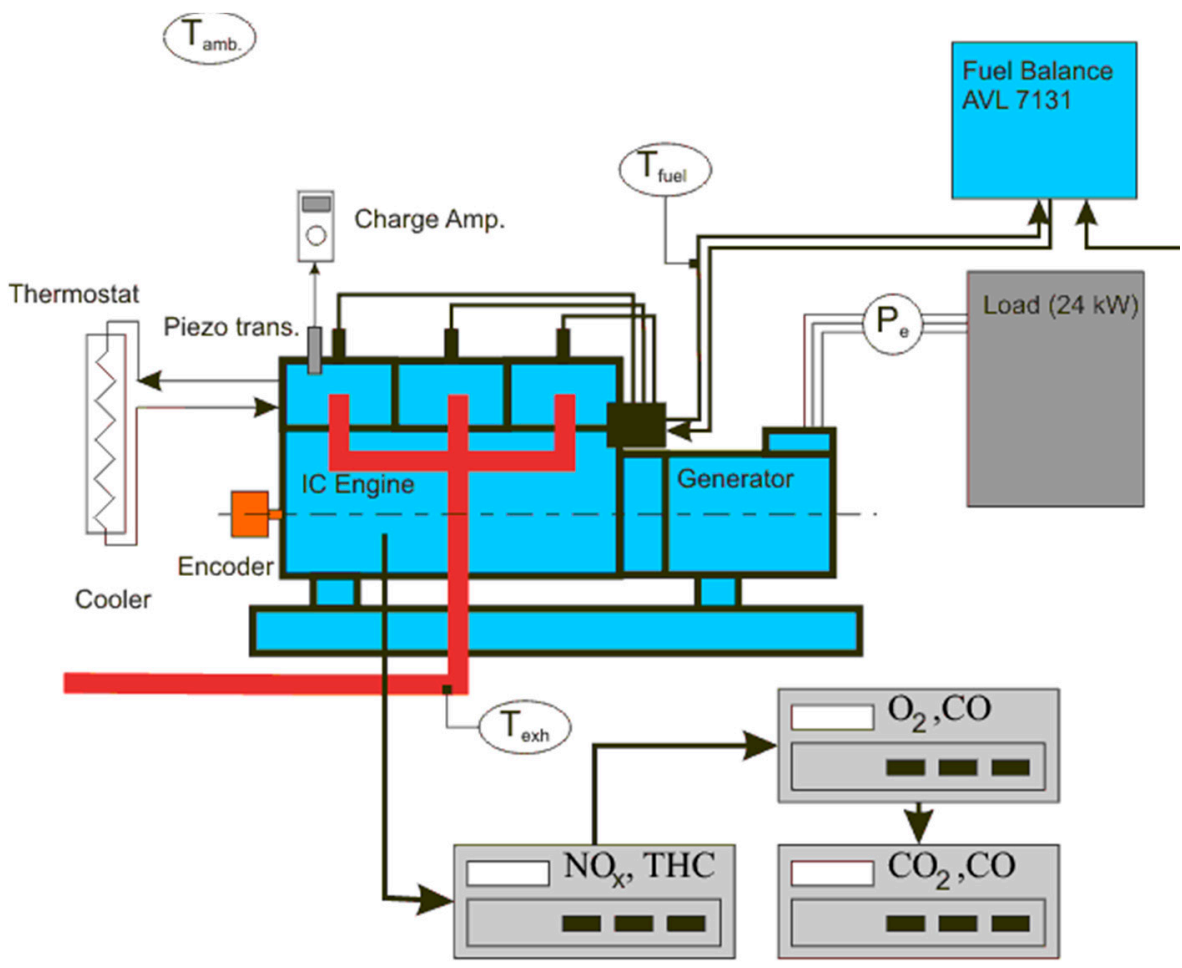

Figure 1. The engine test system.

The combustion chamber pressures and injection tube pressures for D2 fuel and $20 \mathrm{~kW}$ load are shown in Figure 2. For both figures, the averages of 75 cycles at one operating point are shown. In the case of injection tube pressure, the pressure drop observed is associated with the first pressure drop at the start of injection and the pressure oscillations after injection are observed. The high ignition delay characteristic of this engine is clearly observed for the in-cylinder pressure. For pre-injections at 17.5, 15, and 12.5 degrees, the 
maximum pressure location is observed around 5 degrees (ATDC) for smaller pre-injections, the maximum location shifts significantly after TDC.
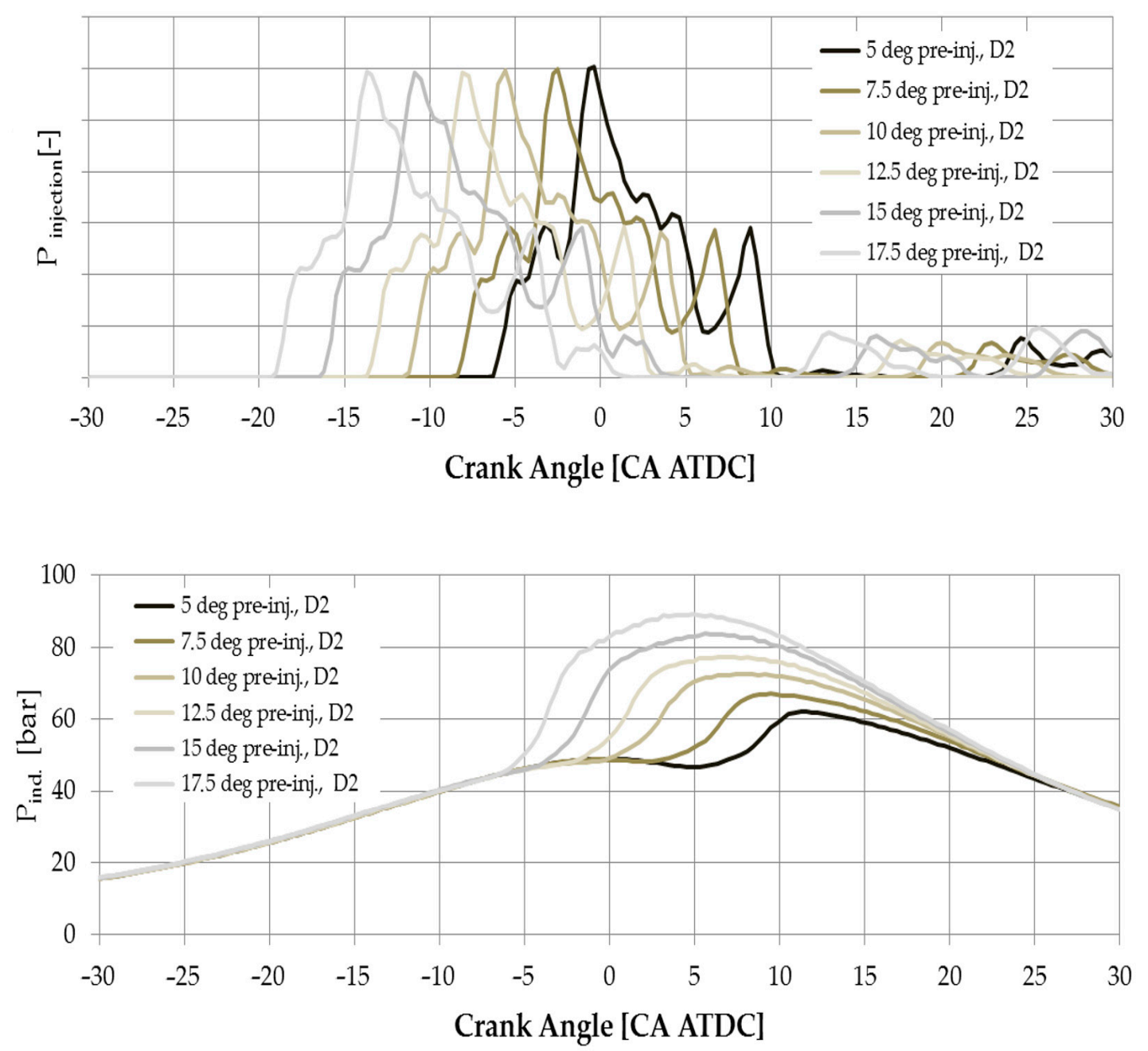

Figure 2. The measured injection tube pressure and the in-cylinder pressure (indicated) pressure in the function of the crank angle at $20 \mathrm{~kW}$ load and D2 fuel.

\subsection{Vibrations and Sound Measurment System}

Vibrations generated by internal combustion (IC) engine depend on disbalanced return motion and rotating parts, cyclic variation in gas pressure, dynamic excitation forces from rotating parts of the engine, and structural properties of the engine mounting mechanism. Stiffness and damping of the engine mounting structure must be high in the low frequency range, and low-in the high frequency range. Proper engine mounting must be used to reduce engine vibrations. Sometimes using mounting elements of appropriate characteristics at the engine-frame point of contact is necessary. Various types of vibration insulation materials are often used to reduce forces transmitted from the engine to the mounting structure.

When conducting experimental tests of the engine, sound of the surrounding environment and vibrations did not affect measurements in the room. The walls of the test room had an acoustic lining made of sound-insulating material, an acoustic door, and a soundproof double-glazed window for viewing inside the engine test chamber from the operator's room. A GRAS 46AE microphone (Frequency range: $3.15 \mathrm{~Hz}$ to $20 \mathrm{kHz}$; Dynamic range: $17 \mathrm{~dB}(\mathrm{~A})$ to $138 \mathrm{~dB}$; Sensitivity: $50 \mathrm{mV} / \mathrm{Pa}$ ) was used to measure sound pressure (Figure 3a(position 3),b)). Engine vibrations were measured at 2 points (Figure 3a(positions 
1 and 2),c) in the longitudinal $(\mathrm{Y})$ and transverse $(\mathrm{X})$ directions using four Bruel\&Kjear 8341 CCLD accelerometers (Frequency range: $0.3-10,000 \mathrm{~Hz}$; Sensitivity: $10 \mathrm{mV} / \mathrm{ms}^{-2}$ ). Data on noise and vibrations were obtained using the Bruel\&Kjear Machine Diagnostic Toolbox. The Machine Diagnostics Toolbox consists of Machine Diagnostics Toolbox Type 9727 and the versatile Machine Diagnostics Toolbox Software Bundle Type 7910. Type 9727 includes the multichannel PULSE data acquisition unit Type 3560-B (5-channel).

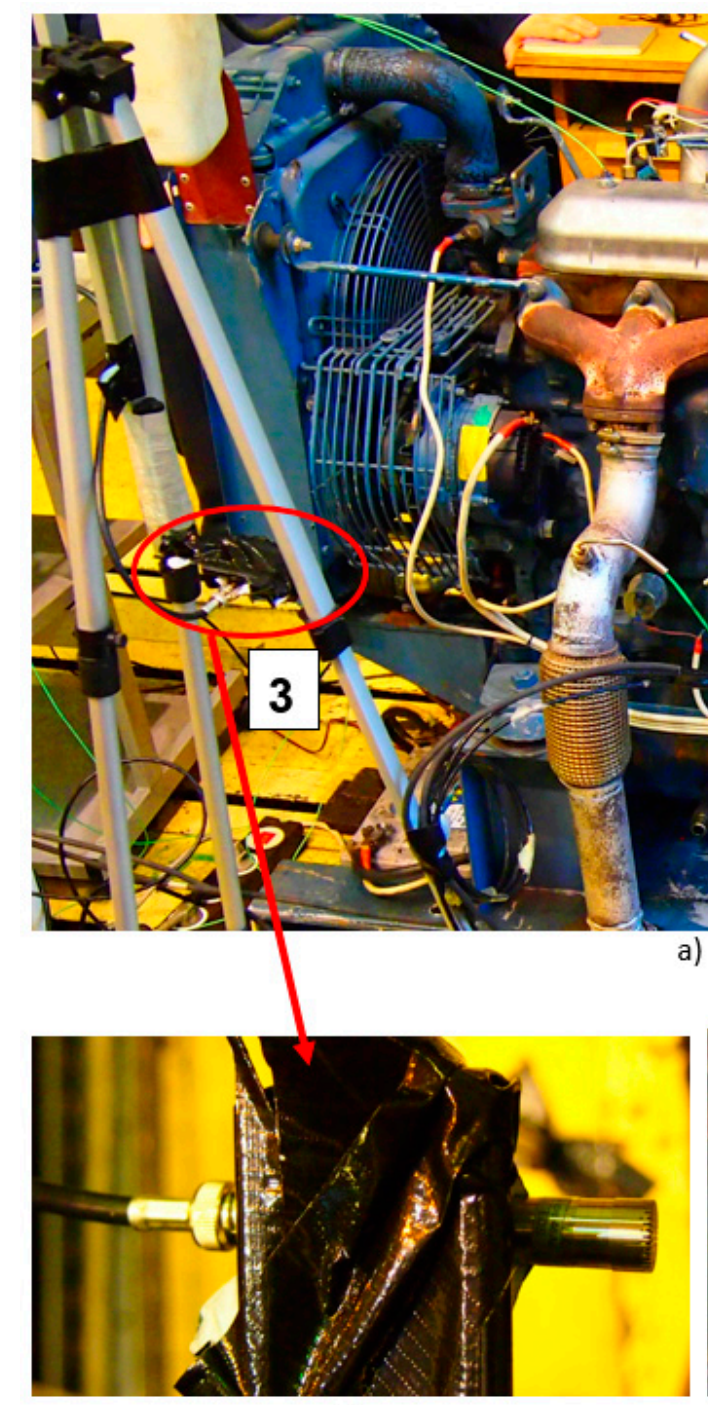

b)

a)

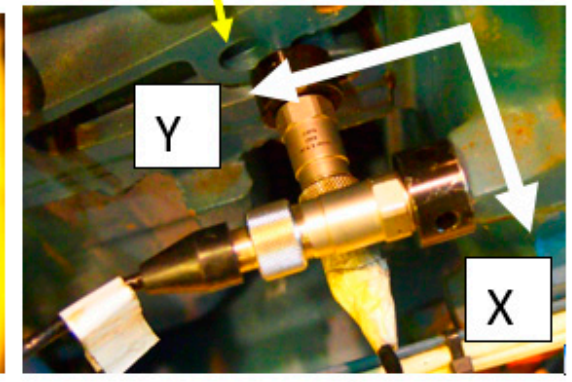

c)

Figure 3. Points of measurement of vibrations and sound pressure: (a) general view of the engine being analyzed and points of measurement of vibrations (points 1 and 2) and sound pressure (point 3); (b) a microphone to measure sound pressure (point 3); (c) accelerometers to measure vibrations (point 2) in $\mathrm{X}$ and $\mathrm{Y}$ directions.

\subsection{Methodology of Statistical Analysis}

Sixteen statistical parameters of time domain were evaluated before performing statistical regression analysis (Table 4). Descriptive analysis for engine exhaust parameters and time domain statistics were also done. Three-step statistical analysis was performed to develop optimal prognostic model for exhausted emissions. 
Table 4. Statistical characteristics in time domain.

\begin{tabular}{cc}
\hline Parameter Expression & Parameter Expression \\
\hline$T_{1}=\bar{X}=\frac{1}{N} \sum_{n=1}^{N} x_{n}$ & $T_{9}=T_{7}-T_{8}$ \\
$T_{2}=R M S=\sqrt{\frac{1}{N} \sum_{n=1}^{N} x_{n}^{2}}$ & $T_{10}=s^{2}=\frac{1}{N-1} \sum_{n=1}^{N}\left(x_{n}-T_{1}\right)^{2}$ \\
$T_{3}=\left(\frac{1}{N} \sum_{n=1}^{N} \sqrt{\left|x_{n}\right|}\right)^{2}$ & $T_{11}=\frac{T_{2}}{T_{4}}$ \\
$T_{4}=\frac{1}{N} \sum_{n=1}^{N}\left|x_{n}\right|$ & $T_{12}=\frac{T_{7}}{T_{2}}$ \\
$T_{5}=\frac{1}{N} \sum_{n=1}^{N}\left(x_{n}-T_{1}\right)^{3}$ & $T_{13}=\frac{T_{7}}{T_{4}}$ \\
$T_{6}=\frac{1}{N} \sum_{n=1}^{N}\left(x_{n}-T_{1}\right)^{4}$ & $T_{14}=\frac{T_{7}}{T_{3}}$ \\
$T_{7}=\max _{n} x_{n}$ & $T_{15}=\frac{T_{5}}{T_{2}{ }^{3}}$ \\
$T_{8}=\min _{n} x_{n}$ & $T_{16}=\frac{T_{6}}{T_{2}{ }^{4}}$ \\
\hline
\end{tabular}

In the first step the best time domain parameter and outcome data acquisition engine point was identified using univariate linear regression model (LRM):

$$
Y^{E}=\alpha+\beta T_{i}^{k}+\varepsilon,
$$

where $Y^{E}$ —exhausted emission counts (dependent variable), E-type of exhausted emission, $T_{i}^{k} i$ th time domain parameter estimate (independent variable) for $k$ th outcome data acquisition engine point, $\alpha$-intercept value, $\beta$-regression parameter for independent variable, $\varepsilon$-random error.

In the second step, one way analysis of variance (ANOVA) model was used to evaluate fuel, engine power and injection timing impact for exhausted emissions. Factor with the highest $R^{2}$ was determined as the strongest predictor for exhausted emissions and further was included into analysis of covariance (ANCOVA) model together with the best time domain parameter:

$$
Y^{E}=\alpha+\beta T_{i}^{k}+\gamma Z_{j}+\mu\left(T_{i}^{k} * Z_{j}\right)+\varepsilon,
$$

where $Y^{E}$ - exhausted emission counts (dependent variable), E-type of exhausted emission, $T_{i}^{k} i$ th time domain parameter estimate (covariate) for $k$ th outcome data acquisition engine point, $Z_{j}$-categorical variable with $j$ levels (independent variable), $\alpha$-regression intercept value, $\beta$-regression parameter for covariate, $\gamma$-regression parameter for independent variable, $\mu$-regression parameter for covariate and independent variable interaction, $\varepsilon$-random error.

In the third step, accuracy between the best prognostic model and real data was evaluated using mean absolute percentage error (MAPE):

$$
M A P E=\frac{1}{n} \sum_{i=1}^{n} \frac{R_{i}^{E}-\hat{Y}_{i}^{E}}{R_{i}^{E}},
$$

where $R_{i}^{E}$-real exhausted emission counts for $i$ th experiment, $\hat{Y}_{i}^{E}$-prognostic exhausted emission counts for $i^{\text {th }}$ experiment, $E$-type of exhausted emission.

\section{Results}

\subsection{Fuel Properties}

A study of physical and chemical properties of fuel revealed that $\mathrm{HVO}$ has $~ 2 \%$ higher and SME 13\% lower heating value compared to conventional diesel fuel, thus the use of SME30 and SME50 increases fuel consumption. A significantly higher SME fuel kinematic and dynamic viscosity are likely to degrade injection quality of these fuel blends, prolong 
the time of evaporation and mixing with air, as well as the combustion time. These changes in SME fuel injection and combustion may lead to a longer rate of heat release as well as a pressure rise during the kinetic (premixed) combustion phase [32,33]. This increases the impact induced by rapidly increasing pressure on the piston and other surfaces of the combustion chamber. However, SMEs contain $\sim 11 \%$ oxygen which improves combustion quality, reduces $\mathrm{CO}, \mathrm{THC}$ emissions and smoke content. Increased oxygen concentration in SME fuels and a more intense rate of heat release increases NOx emissions. First-generation biodiesel (including SME) concentration in fuel is still limited to $7 \%$ in Europe according to EN 590 diesel standard.

$\mathrm{HVO}$ is another type of fuel that may be used to prepare fuel blends. It has a lower density, but its kinematic and dynamic viscosity is close to that of diesel fuel. High HVO cetane number shortens the ignition delay phase of fuel blends, which in turn reduces the rate of heat release and pressure increase in the kinetic (premixed) combustion phase, reducing the mechanical load on the engine and $\mathrm{NO}_{\mathrm{x}}$ emissions upon a decrease in temperatures [34,35]. HVO fuels have a lower $\mathrm{C} / \mathrm{H}$ ratio, which reduces smoke content. SME has a high cold filter plugging point (CFPP) and pour point temperature; therefore, this fuel cannot be used in winter. HVO CFPP and pour point temperatures are low, and these fuels can be mixed with diesel under winter conditions as well. HVO also has a high oxidative stability, good lubricity, thus can be used both pure and in blends with diesel in various proportions.

\subsection{Vibration and Sound Pressure of the Engine}

Determining vibrations and noise emitted by components of a diesel engine is one of the most difficult environmental tasks because each engine mechanism affects vibrations and noise separately.

For each experiment, vibration and sound pressure data were collected from the engine unit with a $3.2 \mathrm{kHz}$ sampling frequency for $2 \mathrm{~s}$. These results are presented in Appendix A.

\subsection{Descriptive Statistics of Exhausted Emission Parameters}

Descriptive statistical analysis revealed that engine power was strongly associated with almost all exhausted emission parameters. $\mathrm{O}_{2}$ and mass flow of the air were inversely proportional to increased engine power. The average $\mathrm{O}_{2}$ decreased up to $42.0 \%$ from $17.4 \mathrm{~V} \%$ at $4 \mathrm{~kW}$ engine power to $10.1 \mathrm{~V} \%$ at $20 \mathrm{~kW}$ engine power, while mass flow of the air had more slightly decrease $(1.7 \%)$. Other parameters were directly proportional. Huge value jump regarding increased power was observed in $\mathrm{NO}_{\mathrm{x}}(289.5 \%), \mathrm{CO}(221.5 \%)$ and $\mathrm{CO}_{2}(200.0 \%)$ (Table 5).

Any type of fuel had a major impact for CO and THC: The mean (SD) variated from 361 (233.4) ppm to 514 (292.7) ppm and from 102 (29.3) ppm to 139 (30.9) ppm for CO and THC, respectively. Fuels based on SME blend showed higher levels of fuel mass flow, CO, $\mathrm{CO}_{2}, \mathrm{NO}_{\mathrm{x}}, \mathrm{THC}, \mathrm{t}_{\mathrm{air}}, \mathrm{t}_{\text {fuel }}, \mathrm{t}_{\text {exhaust }}$ than $\mathrm{HVO}$ blends, while $\mathrm{CO}_{\text {Sick }}$ and air mass flow were slightly higher in $\mathrm{HVO}$ based blends. $\mathrm{O}_{2}$ value remained independent from fuel blends (Table 5).

Increased injection timing was extremely associated with increased $\mathrm{NO}_{\mathrm{x}}$. Mean (SD) of $\mathrm{NO}_{\mathrm{x}}$ value increased from 352 (194.5) ppm at 5 CAD BTDC to 1000 (495.0) ppm at 17.5 CAD BTDC for injection timing at $12 \mathrm{~kW}$. Interestingly, THC achieved minimal values at 10 CAD BTDC with mean (SD) 111 (28.4) ppm, while moving towards to lower and higher injection timing category THC loads started to grow. The same tendency was observed in CO loads where minimal value with mean (SD) 423 (311.3) ppm was achieved at 12.5 CAD BTDC. Lower mean $t_{\text {exaust }}$ parameter values were associated with increased

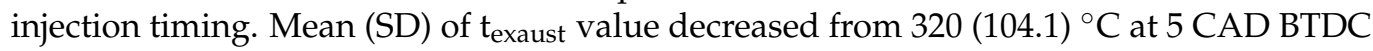
to $301(107.0)^{\circ} \mathrm{C}$ at $17.5 \mathrm{CAD}$ BTDC. 
Table 5. Descriptive Statistical Analysis for Engine Exhausted Emission Parameters.

\begin{tabular}{|c|c|c|c|c|c|c|}
\hline & $\begin{array}{c}\text { Fuel mass flow } \\
{[\mathrm{kg} / \mathrm{h}]} \\
\text { Mean (SD) }\end{array}$ & $\begin{array}{c}\text { CO [ppm] } \\
\text { Mean (SD) }\end{array}$ & $\begin{array}{l}\mathrm{CO}_{2}[\mathrm{~V} \%] \\
\text { Mean (SD) }\end{array}$ & $\begin{array}{l}\mathrm{NO}_{x}[\mathrm{ppm}] \\
\text { Mean }(\mathrm{SD})\end{array}$ & $\begin{array}{l}\text { THC [ppm] } \\
\text { Mean (SD) }\end{array}$ & $\begin{array}{c}\mathrm{CO}_{\text {Sick }}[\mathrm{V} \%] \\
\text { Mean }(\mathrm{SD})\end{array}$ \\
\hline Total & $3.2(1.29)$ & $488(324.1)$ & $\begin{array}{c}4.5(1.95) \\
\text { Engine Power }\end{array}$ & 1000 (495) & $120(37.6)$ & $0.07(0.027)$ \\
\hline $4 \mathrm{~kW}$ & $1.9(0.07)$ & 297 (55.5) & $2.4(0.10)$ & $285(106.8)$ & 103 (19.0) & $0.05(0.011)$ \\
\hline $8 \mathrm{~kW}$ & $2.5(0.09)$ & 296 (43.7) & $3.4(0.09)$ & $422(155.1)$ & $105(19.0)$ & $0.05(0.012)$ \\
\hline $12 \mathrm{~kW}$ & $3.3(0.43)$ & $260(50.7)$ & $4.6(0.51)$ & $678(279.5)$ & 107 (27.2) & $0.05(0.012)$ \\
\hline $20 \mathrm{~kW}$ & $5.0(0.21)$ & 955 (98.3) & $\begin{array}{c}7.2(0.15) \\
\text { Type of Fuel }\end{array}$ & $1110(369.9)$ & $158(26.6)$ & $0.09(0.021)$ \\
\hline D100 & 3.1 (1.19) & $361(233.4)$ & 4.5 (1.94) & $606(419.6)$ & $102(29.3)$ & $0.07(0.020)$ \\
\hline HVO30 & $3.0(1.14)$ & 413 (295.3) & $4.3(1.86)$ & $605(386.6)$ & $118(20.1)$ & $0.08(0.020)$ \\
\hline HVO50 & $3.1(1.18)$ & $421(316.3)$ & $4.3(1.85)$ & $578(377.1)$ & $105(32.4)$ & $0.07(0.021)$ \\
\hline SME30 & $3.5(1.30)$ & 487 (313.2) & $4.6(1.88)$ & 711 (434.7) & $128(35.5)$ & $0.05(0.014)$ \\
\hline SME50 & $3.3(1.28)$ & $514(292.7)$ & $4.4(1.83)$ & 645 (412.0) & 139 (30.9) & $0.05(0.013)$ \\
\hline \multicolumn{7}{|c|}{ Injection Timing at $12 \mathrm{~kW}$} \\
\hline 5 CAD BTDC & $3.2(1.24)$ & $440(250.0)$ & $4.4(1.87)$ & $352(194.5)$ & $128(27.9)$ & $0.06(0.017)$ \\
\hline 7.5 CAD BTDC & $3.2(1.22)$ & $439(285.6)$ & $4.4(1.86)$ & $436(247.4)$ & $124(26.4)$ & $0.06(0.019)$ \\
\hline 10 CAD BTDC & $3.2(1.22)$ & $429(313.0)$ & $4.4(1.86)$ & $545(290.2)$ & $111(28.4)$ & $0.06(0.022)$ \\
\hline $\begin{array}{c}\text { 12.5 CAD } \\
\text { BTDC }\end{array}$ & $3.2(1.23)$ & 423 (311.3) & $4.4(1.88)$ & $645(341.7)$ & $112(34.7)$ & $0.06(0.023)$ \\
\hline 15 CAD BTDC & $3.2(1.25)$ & $431(308.7)$ & $4.4(1.89)$ & $806(411.2)$ & $116(39.2)$ & $0.06(0.025)$ \\
\hline $\begin{array}{c}\text { 17.5 CAD } \\
\text { BTDC }\end{array}$ & $3.2(1.29)$ & 488 (324.1) & $4.5(1.95)$ & $1000(495.0)$ & $120(37.6)$ & $0.07(0.027)$ \\
\hline & $\begin{array}{c}\mathrm{O}_{2}[\mathrm{~V} \%] \\
\text { Mean (SD) }\end{array}$ & $\begin{array}{c}\mathrm{t}_{\text {air }}\left[{ }^{\circ} \mathrm{C}\right] \\
\text { Mean (SD) }\end{array}$ & $\begin{array}{c}\text { Air mass flow } \\
{[\mathrm{kg} / \mathrm{h}]} \\
\text { Mean }(\mathrm{SD})\end{array}$ & $\begin{array}{c}\mathrm{t}_{\text {fuel }}\left[{ }^{\circ} \mathrm{C}\right] \\
\text { Mean (SD) }\end{array}$ & \multicolumn{2}{|c|}{$\begin{array}{l}\mathrm{t}_{\text {exhaust }}\left[{ }^{\circ} \mathrm{C}\right] \\
\text { Mean }(\mathrm{SD})\end{array}$} \\
\hline Total & $14.3(2.95)$ & $21.6(1.94)$ & $\begin{array}{l}133.1(1.53) \\
\text { Engine Power }\end{array}$ & $27.9(2.43)$ & \multicolumn{2}{|c|}{$301(107.0)$} \\
\hline $4 \mathrm{~kW}$ & $17.4(0.17)$ & $20.8(1.83)$ & $134.4(0.94)$ & $27.6(2.66)$ & \multicolumn{2}{|c|}{$198(8.3)$} \\
\hline $8 \mathrm{~kW}$ & $16.0(0.14)$ & $20.9(2.02)$ & $134.5(1.03)$ & $27.5(2.19)$ & \multicolumn{2}{|c|}{$247(9.6)$} \\
\hline $12 \mathrm{~kW}$ & $14.2(0.76)$ & $21.8(2.04)$ & $133.7(1.18)$ & $28.2(2.52)$ & \multicolumn{2}{|c|}{$311(32.7)$} \\
\hline $20 \mathrm{~kW}$ & $10.1(0.26)$ & $22.6(2.49)$ & $\begin{array}{l}132.1(1.21) \\
\text { Type of Fuel }\end{array}$ & $28.6(3.27)$ & \multicolumn{2}{|c|}{$464(10.1)$} \\
\hline D100 & $14.2(2.92)$ & $23.6(1.27)$ & $132.9(1.01)$ & $31.7(0.56)$ & \multicolumn{2}{|c|}{$306(103.3)$} \\
\hline HVO30 & $14.5(2.82)$ & $20.1(1.99)$ & $134.6(1.53)$ & $25.4(1.57)$ & \multicolumn{2}{|c|}{$297(100.8)$} \\
\hline HVO50 & $14.5(2.85)$ & $19.0(0.79)$ & $134.7(0.63)$ & $25.3(1.55)$ & \multicolumn{2}{|c|}{$300(100.7)$} \\
\hline SME30 & $14.1(2.83)$ & $22.7(1.54)$ & $132.6(1.34)$ & $29.1(1.19)$ & \multicolumn{2}{|c|}{$328(108.3)$} \\
\hline SME50 & $14.6(2.70)$ & $22.5(0.97)$ & $\begin{array}{c}133.3(1.17) \\
\text { Injection Timing }\end{array}$ & $28.6(0.85)$ & \multicolumn{2}{|c|}{301 (104.5) } \\
\hline 5 CAD BTDC & $14.4(2.81)$ & $21.5(2.58)$ & $134.2(1.41)$ & $28.1(3.19)$ & \multicolumn{2}{|c|}{$320(104.1)$} \\
\hline 7.5 CAD BTDC & $14.4(2.79)$ & $21.7(2.35)$ & $133.8(1.57)$ & $28.0(2.87)$ & \multicolumn{2}{|c|}{$310(103.9)$} \\
\hline 10 CAD BTDC & $14.4(2.80)$ & $21.5(2.43)$ & $133.7(1.55)$ & $27.9(2.83)$ & \multicolumn{2}{|c|}{309 (103.5) } \\
\hline $\begin{array}{l}\text { 12.5 CAD } \\
\text { BTDC }\end{array}$ & $14.5(2.85)$ & $21.3(2.05)$ & $133.6(1.25)$ & $27.9(2.63)$ & \multicolumn{2}{|c|}{$300(103.5)$} \\
\hline 15 CAD BTDC & $14.4(2.85)$ & $21.6(2.11)$ & $133.3(1.27)$ & $27.9(2.47)$ & \multicolumn{2}{|c|}{$298(104.0)$} \\
\hline $\begin{array}{l}\text { 17.5 CAD } \\
\text { BTDC }\end{array}$ & $14.3(2.95)$ & $21.6(1.94)$ & $133.1(1.53)$ & $27.9(2.43)$ & \multicolumn{2}{|c|}{$301(107.0)$} \\
\hline
\end{tabular}

Other exhausted emission parameters remained stable at various injection timing at $12 \mathrm{~kW}$ (Table 5).

\subsection{Step 1: Significant Vibro-Acoustic Parameters in Time Domain}

A total of 16 time domain parameters for each 5 vibro-acoustic engine outcomes parameters (longitudinal $1\left(\mathrm{LONG}_{1}\right)$, longitudinal $2\left(\mathrm{LONG}_{2}\right)$, traverse $1\left(\mathrm{TRAV}_{1}\right)$, traverse $2\left(\mathrm{TRAV}_{2}\right)$ and sound pressure (SP) (Figure 3$)$ ) were evaluated as independent prognostic variables using univariate LRM. Regression analysis revealed that even 8-11 exhausted emission parameters could be prognosed using parameters $T_{2}-T_{11}$ from all 5 vibro-acoustic 
engine outcomes. Also, 10 exhausted emission parameters could be prognosed using $T_{15}$ in $\mathrm{LONG}_{1}$ and $T R A V_{2}$ point and $T_{16}$ in $\mathrm{TRAV}_{1}$ and $T R A V_{2}$ point, however $T_{15}$ was weak prognostic parameter at $L O N G_{2}$ and $T R A V_{1}$ engine points. Only one parameter $T_{11}$ calculated from $\mathrm{TRAV}_{1}$ engine data acquisition point had statistically significant impact for all 11 engine exhausted emission parameters and was defined as the best prognostic parameter in univariate LRM (Table 6). Due to strong prognostic value only $T_{11}$ gathered from $\mathrm{TRAV}_{1}$ was included in the further step 2 statistical ANCOVA analysis as model covariate variable.

Table 6. Cumulative counts of statistically significant time domain statistics predicting ecological engine outcome parameters.

\begin{tabular}{cccccc}
\hline & Longitudinal 1 & Longitudinal 2 & Traverse 1 & Traverse 2 & Sound Pressure \\
\hline$T_{1}$ & - & 1 & - & 1 & - \\
$T_{2}$ & 10 & 10 & 10 & 8 & 9 \\
$T_{3}$ & 10 & 10 & 10 & 8 & 9 \\
$T_{4}$ & 10 & 10 & 10 & 8 & 9 \\
$T_{5}$ & 10 & 8 & 9 & 10 & 10 \\
$T_{6}$ & 10 & 10 & 10 & 8 & 9 \\
$T_{7}$ & 10 & 9 & 10 & 8 & 10 \\
$T_{8}$ & 9 & 9 & 10 & 8 & 9 \\
$T_{9}$ & 10 & 9 & 10 & 8 & 9 \\
$T_{10}$ & 10 & 10 & 10 & 8 & 9 \\
$T_{11}$ & 10 & 9 & 11 & 9 & 9 \\
$T_{12}$ & - & - & 3 & 4 & 7 \\
$T_{13}$ & 7 & 1 & 8 & 7 & 7 \\
$T_{14}$ & 8 & 1 & 9 & 8 & 8 \\
$T_{15}$ & 10 & - & 5 & 10 & 9 \\
$T_{16}$ & 8 & 5 & 10 & 10 & 7 \\
\hline
\end{tabular}

Descriptive analysis showed that engine power was strongly and directly associated with increased $T_{11}$ at $T R A V_{1}$ : the median (Q1-Q3) $T_{11}$ at $\mathrm{TRAV}_{1}$ was 1.41 (1.38-1.43), 1.42 (1.39-1.46), $1.46(1.45-1.48)$, and $1.51(1.47-1.53)$ at $4 \mathrm{~kW}, 8 \mathrm{~kW}, 12 \mathrm{~kW}$, and $20 \mathrm{~kW}$ engine power, respectively (Figure $4 a$ ).

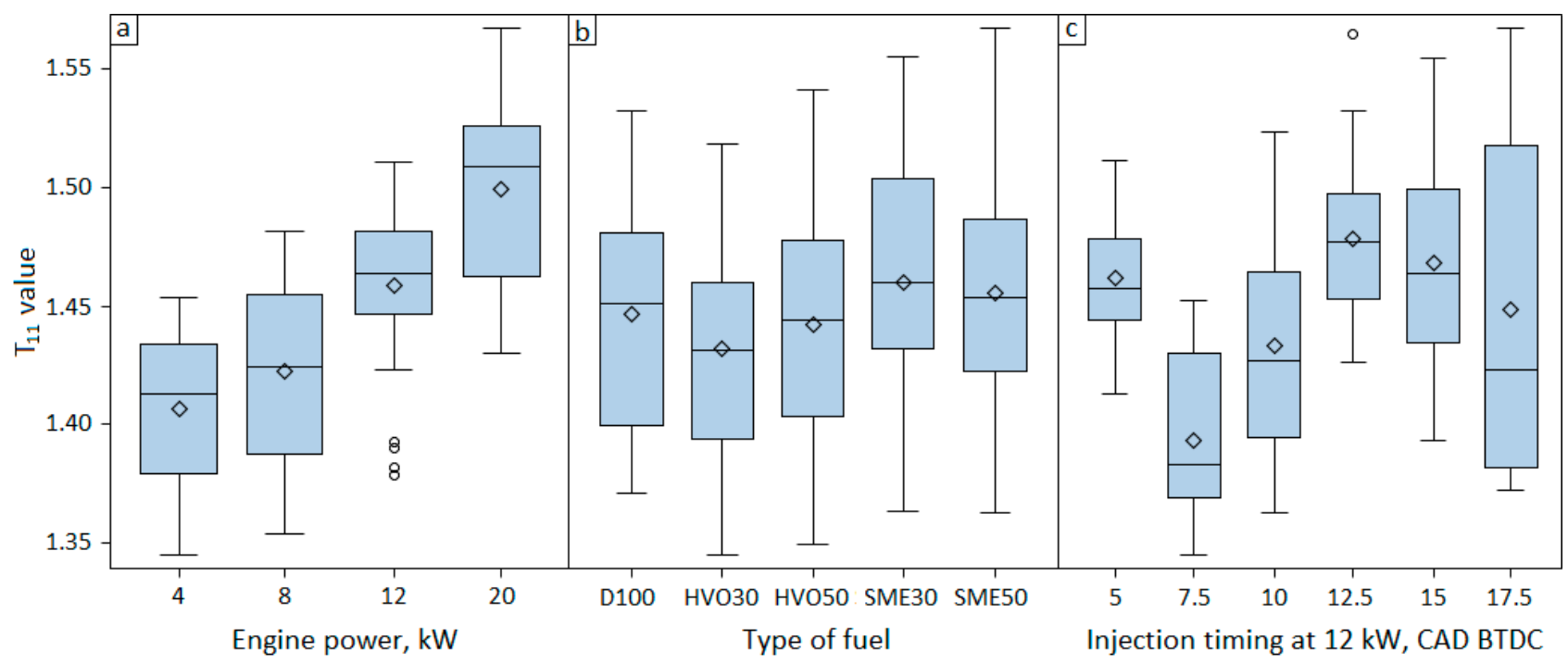

Figure 4. Distribution of time domain parameter $T_{11}$ calculated from $\operatorname{TRAV}_{1}$ by (a) Engine power, (b) Type of fuel, and (c) Injection timing. 
It should be noted that variation was very low in power groups. Distribution of $T_{11}$ at $\mathrm{TRAV}_{1}$ remained to be independent from various type of fuels. Also, the variation was increased in each of fuels compared with variation in engine power groups. It could be explained that engine power is very strong factor for the shape of $T_{11}$ at $T R A V_{1}$ distribution and have significant impact in fuel blends groups (Figure $4 \mathrm{~b}$ ).

Distributions $T_{11}$ at $T R A V_{1}$ in various injection timing groups were slightly different. Interestingly, there was no any linear tendency injection timing and $T_{11}$ at $T_{R A V}$ values. The minimum $T_{11}$ at TRAV 1 was observed in 7.5 CAD BTDC group with median (Q1-Q3) 1.38 (1.37-1.43), while maximum was observed in 12.5 CAD BTDC group 1.48 (1.45-1.50) (Figure 4c).

Figure 4 shows parameter $T_{11}$ distribution in engine power, type of fuel and injection timing categories. $T_{11}$ had moderate (Spearman's $\rho=0.688, p<0.001$ ) and weak (Spearman's $\rho=0.194, p=0.036$ ) correlation with engine power and injection angle, respectively, and there was no correlation with type of fuel.

\subsection{Step 2: ANCOVA Model for Engine Exhausted Emission Parameters}

In this step one-way ANOVA analysis was performed to evaluate prognostic impact of engine power, type of fuel and injection timing for all 11 exhausted emission parameters. Analysis revealed that engine power had the highest $R^{2}$ values for fuel mass flow, $\mathrm{CO}, \mathrm{CO}_{2}$,

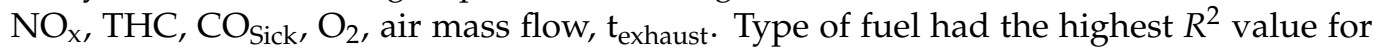
$t_{\text {air }}$ and $t_{\text {fuel }}$ while fuel injection timing had very low $R^{2}$ values and was not included in further analysis (Table 7).

Table 7. $R^{2}$ Estimates for engine exhausted emission parameters.

\begin{tabular}{|c|c|c|c|c|}
\hline $\begin{array}{c}\text { Exhausted Emission } \\
\text { Parameter }\end{array}$ & $T_{11}$ at $\operatorname{TRAV}_{\%}{ }^{1}$ & $\begin{array}{c}\text { Type of Fuel } \\
\%\end{array}$ & $\begin{array}{c}\text { Engine Power }{ }^{2}, \\
\%\end{array}$ & $\begin{array}{c}\text { Injection Timing }^{2}, \\
\%\end{array}$ \\
\hline Fuel mass flow & $51.3 *$ & 2.5 & $96.0 *$ & $<0.1$ \\
\hline $\mathrm{CO}$ & $33.2 *$ & 3.4 & $95.3 *$ & 0.5 \\
\hline $\mathrm{CO}_{2}$ & $48.6^{*}$ & 0.6 & $97.8 *$ & $<0.1$ \\
\hline $\mathrm{NO}_{\mathrm{x}}$ & $52.6 *$ & 1.3 & $61.8 *$ & $29.9 *$ \\
\hline THC & 29.6 * & $18.3 *$ & $50.2 *$ & 3.6 \\
\hline $\mathrm{CO}_{\text {Sick }}$ & $13.8 *$ & $35.3 *$ & $57.6 *$ & 9.8 \\
\hline $\mathrm{O}_{2}$ & $47.9 *$ & 4.9 & $97.8 *$ & 0.1 \\
\hline$t_{\text {air }}$ & $7.9 *$ & $62.5 *$ & $11.3^{*}$ & 0.4 \\
\hline Air mass flow & $30.9 *$ & $37.3 *$ & $44.0 *$ & 6.1 \\
\hline$t_{\text {fuel }}$ & $3.7 *$ & $80.4 *$ & 2.6 & 0.1 \\
\hline$t_{\text {exhaust }}$ & $47.3 *$ & 1.2 & $96.9 *$ & 0.6 \\
\hline
\end{tabular}

${ }^{1} R^{2}$ estimated using univariate LRM (Step 1). ${ }^{2} R^{2}$ estimated using one-way ANOVA model (Step 2). ${ }^{*}$ Parameter had statistically significant impact for respective exhausted emission parameter.

Engine power as independent factor has very high predictive model fit for fuel mass flow, $\mathrm{CO}, \mathrm{CO}_{2}, \mathrm{O}_{2}$ and $\mathrm{t}_{\text {exhaust }}$ with $R^{2}>90$ (Table 7).

$R^{2}$ for $T_{11}$ at TRAV 1 was somewhat lower than engine power or type of fuel but remained still statistically significant for all exhausted emission parameters (Table 7).

Finally, from Table 7 the best predictive models for exhausted emission were developed of $T_{11}$ at TRAV 1 , engine power and type of fuel. Regarding ANCOVA Equation (2) further predictive models with interaction of categorical variable and covariate were concluded:

- for fuel mass flow, $\mathrm{CO}, \mathrm{CO}_{2}, \mathrm{NO}_{\mathrm{x}}, \mathrm{THC}, \mathrm{CO}_{\text {Sick}}, \mathrm{O}_{2}$, mass flow of the air, and $\mathrm{t}_{\text {exhaust }}$

$$
Y=\alpha+\beta *\left[T_{11} \text { at TRAV1 }\right]+\gamma * \text { power }+\mu *\left(\left[T_{11} \text { at TRAV1 }\right] * \text { power }\right)+\varepsilon ;
$$

- $\quad$ for $t_{\text {air }}$, and $t_{\text {fuel }}$

$$
Y=\alpha+\beta *\left[T_{11} \text { at TRAV1 }\right]+\gamma * f u e l+\mu *\left(\left[T_{11} \text { at TRAV1 }\right] * f u e l\right)+\varepsilon .
$$

Table 8 shows regression parameter estimates and $R^{2}$ values calculated from regression Equations (3) and (4). All $R^{2}$ values were higher in ANCOVA model than in ANOVA model 
and much higher than in univariate LRM. The major $R^{2}$ improvement between ANOVA and ANCOVA models was reached in $\mathrm{NO}_{x}$ and $t_{\text {air }}$ with $12.4 \%$ and $9.9 \%$ increment, respectively. Exhaust parameters with $R^{2}>90 \%$ in ANOVA model had very low $(<1 \%) R^{2}$ increment in ANCOVA model.

Table 8. ANCOVA model parameter estimates for engine exhausted emission parameters.

\begin{tabular}{|c|c|c|c|c|c|c|c|c|c|c|c|}
\hline & \multirow{2}{*}{ Intercept $(\alpha)$} & \multirow{2}{*}{$T_{11}$ at $\operatorname{TRAV}_{1}(\beta)$} & \multicolumn{4}{|c|}{ Engine Power $(\gamma)$} & \multicolumn{4}{|c|}{$T_{11}$ at $\mathrm{TRAV}_{1} *$ Engine Power $(\mu)$} & \multirow{2}{*}{$\begin{array}{c}R^{2}, \\
\%\end{array}$} \\
\hline & & & $8 \mathrm{~kW}$ & \multicolumn{2}{|c|}{$12 \mathrm{~kW}$} & $20 \mathrm{~kW}$ & $8 \mathrm{~kW}$ & \multicolumn{2}{|c|}{$12 \mathrm{~kW}$} & $20 \mathrm{~kW}$ & \\
\hline $\begin{array}{l}\text { Fuel mass } \\
\text { flow }\end{array}$ & 1.486 & 0.277 & 0.697 & \multicolumn{2}{|c|}{-4.470} & -0.318 & -0.022 & \multicolumn{2}{|c|}{4.050} & 2.309 & 96.6 \\
\hline $\mathrm{CO}$ & 291.7 & 3.8 & -87.7 & \multicolumn{2}{|c|}{-396.9} & -1125.7 & 60.5 & \multicolumn{2}{|c|}{246.6} & 1190.6 & 96.0 \\
\hline $\mathrm{CO}_{2}$ & 2.626 & -0.166 & 0.279 & \multicolumn{2}{|c|}{-5.281} & 4.726 & 0.484 & \multicolumn{2}{|c|}{5.108} & 0.085 & 98.0 \\
\hline $\mathrm{NO}_{\mathrm{x}}$ & 1059.3 & -550.3 & -1496.5 & \multicolumn{2}{|c|}{-4982.7} & -9382.1 & 1154.6 & \multicolumn{2}{|c|}{3704.7} & 6842.1 & 74.2 \\
\hline $\mathrm{THC}$ & 141.1 & -27.3 & -119.4 & \multicolumn{2}{|c|}{-90.4} & -556.3 & 86.0 & \multicolumn{2}{|c|}{65.9} & 409.5 & 56.2 \\
\hline $\mathrm{CO}_{\text {Sick }}$ & 0.131 & -0.055 & -0.057 & \multicolumn{2}{|c|}{0.089} & 0.025 & 0.041 & \multicolumn{2}{|c|}{-0.060} & 0.012 & 58.8 \\
\hline $\mathrm{O}_{2}$ & 16.59 & 0.59 & -0.06 & \multicolumn{2}{|c|}{7.90} & -7.63 & -0.98 & \multicolumn{2}{|c|}{-7.61} & 0.19 & 98.0 \\
\hline $\begin{array}{l}\text { Air mass } \\
\text { flow }\end{array}$ & 138.35 & -2.83 & 0.02 & \multicolumn{2}{|c|}{12.37} & 4.77 & 0.09 & \multicolumn{2}{|c|}{-8.82} & -4.53 & 47.6 \\
\hline \multirow[t]{2}{*}{$t_{\text {exhaust }}$} & 143.8 & 38.5 & 109.2 & \multirow{2}{*}{\multicolumn{2}{|c|}{$\begin{array}{c}-222.3 \\
\text { Type of Fuel }(\gamma)\end{array}$}} & 415.3 & -42.9 & \multicolumn{2}{|c|}{228.9} & -102.8 & 97.1 \\
\hline & Intercept & $T_{11}$ at $\operatorname{TRAV}_{1}(\beta)$ & & & & & \multicolumn{4}{|c|}{$T_{11}$ at TRAV $_{1} *$ Type of Fuel $(\mu)$} & $R^{2}$ \\
\hline$t_{\text {air }}$ & $\begin{array}{c}(\alpha) \\
22.08\end{array}$ & 1.04 & -33.13 & 11.19 & $\begin{array}{l}\text { SMIESU } \\
-27.10\end{array}$ & $\begin{array}{l}\text { SMESU } \\
-9.54\end{array}$ & $\begin{array}{l}\text { HVU30 } \\
20.70\end{array}$ & $\begin{array}{l}\text { HVU50 } \\
-10.96\end{array}$ & $\begin{array}{c}\text { SMIESU } \\
17.91\end{array}$ & $\begin{array}{l}\text { SMESU } \\
5.82\end{array}$ & 72.4 \\
\hline$t_{\text {fuel }}$ & 24.14 & 5.21 & -22.59 & 27.62 & -10.48 & -7.69 & 11.43 & -23.55 & 5.54 & 3.13 & 85.8 \\
\hline
\end{tabular}

Engine power of $4 \mathrm{~kW}$ and fuel type of D100 were defined as reference values with 0 model parameter estimates. ${ }^{*}$ Interaction of ANCOVA parameters.

\subsection{Step 3: Prediction Model Accuracy}

Regression model with independent predictor $T_{11}$ at $T R A V_{1}$ alone remained the worst prediction model regarding relatively high MAPE values. On average, ANOVA and ANCOVA models were 3.3 times more accurate that univariate LRM and remained as strong prediction models for exhausted emissions. Tremendous prediction accuracy improvement switching from univariate LRM to in ANOVA and ANCOVA models was fixed in fuel mass flow, $\mathrm{CO}, \mathrm{CO}_{2}, \mathrm{O}_{2}$ and $t_{\text {exhaust }}$ parameters. However, $\mathrm{THC}$, $\mathrm{t}_{\mathrm{air}}$, and $\mathrm{t}_{\text {fuel }}$ had lower accuracy improvement than other parameters but still ANOVA and ANCOVA models had showed significant accuracy improvement. Only prediction for air mass flow parameter had not been improved through all prediction models. (Figure 5).

Step 2 ANCOVA model with two factors ( $T_{11}$ at $T R A V_{1}$ and engine power or type of fuel) remained the best predictive model for all 11 exhausted emission parameters with the lowest MAPE values for all exhausted emission parameters (Figure 5). The most MAPE reduction was defined in $\mathrm{NO}_{\mathrm{x}}, \mathrm{t}_{\text {air }}$, and $\mathrm{t}_{\text {fuel }}$ comparing ANOVA and ANCOVA models. Figure 6a shows that increased prediction accuracy was observed in higher engine power regardless type of fuel, whereas vibration covariate has not had any influence in low (4 kW and $8 \mathrm{~kW}$ ) engine power. Furthermore, vibration covariate has also not had any influence in pure diesel engines. However, $T_{11}$ at $\mathrm{TRAV}_{1}$ influence greatly improved while diesel mixtures were used (Figure 6b,c). 


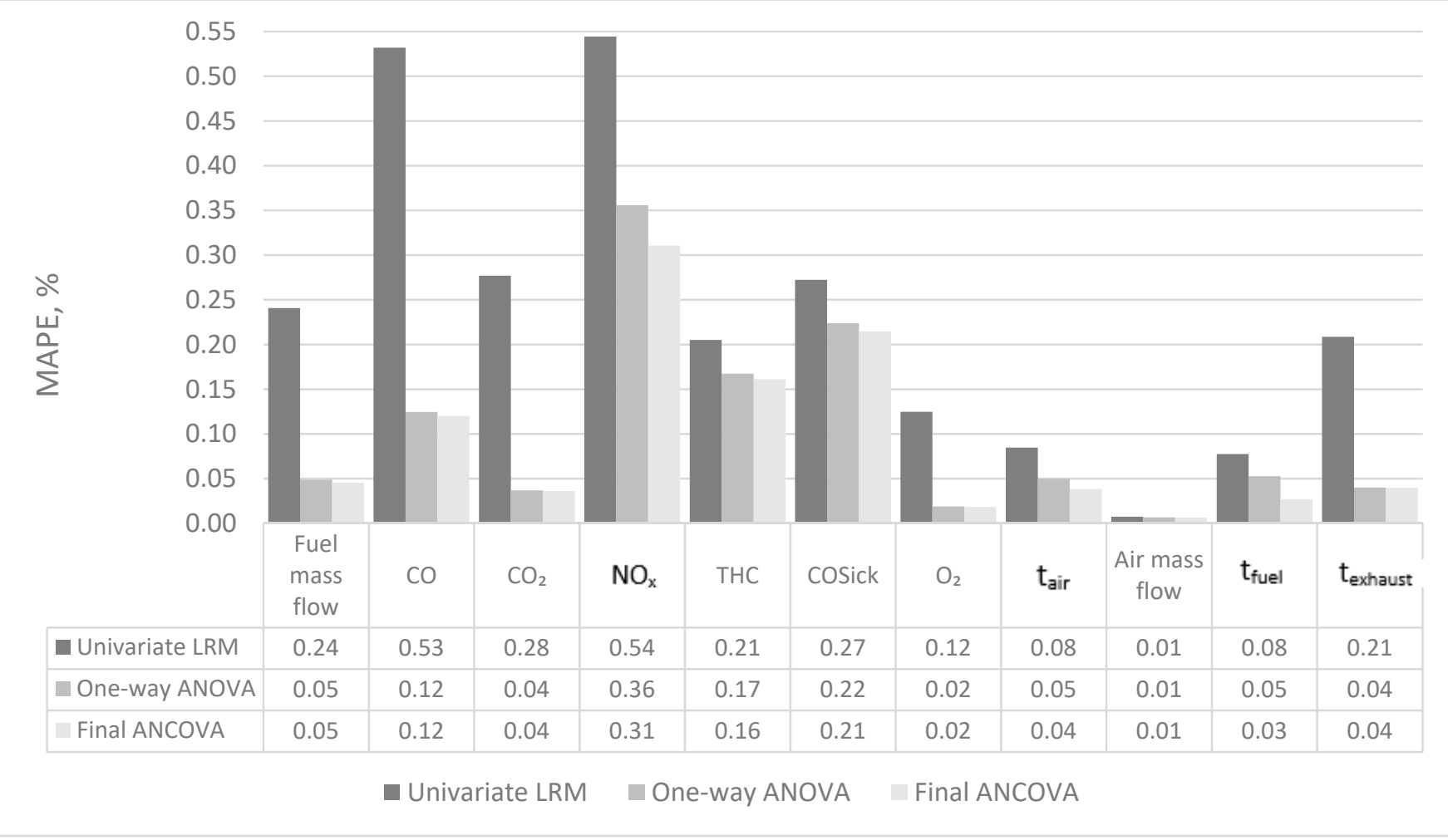

Figure 5. Mean absolute percentage error for exhausted emission parameters calculated from univariate linear regression model (LRM), one-way ANOVA and final ANVOVA.

a)

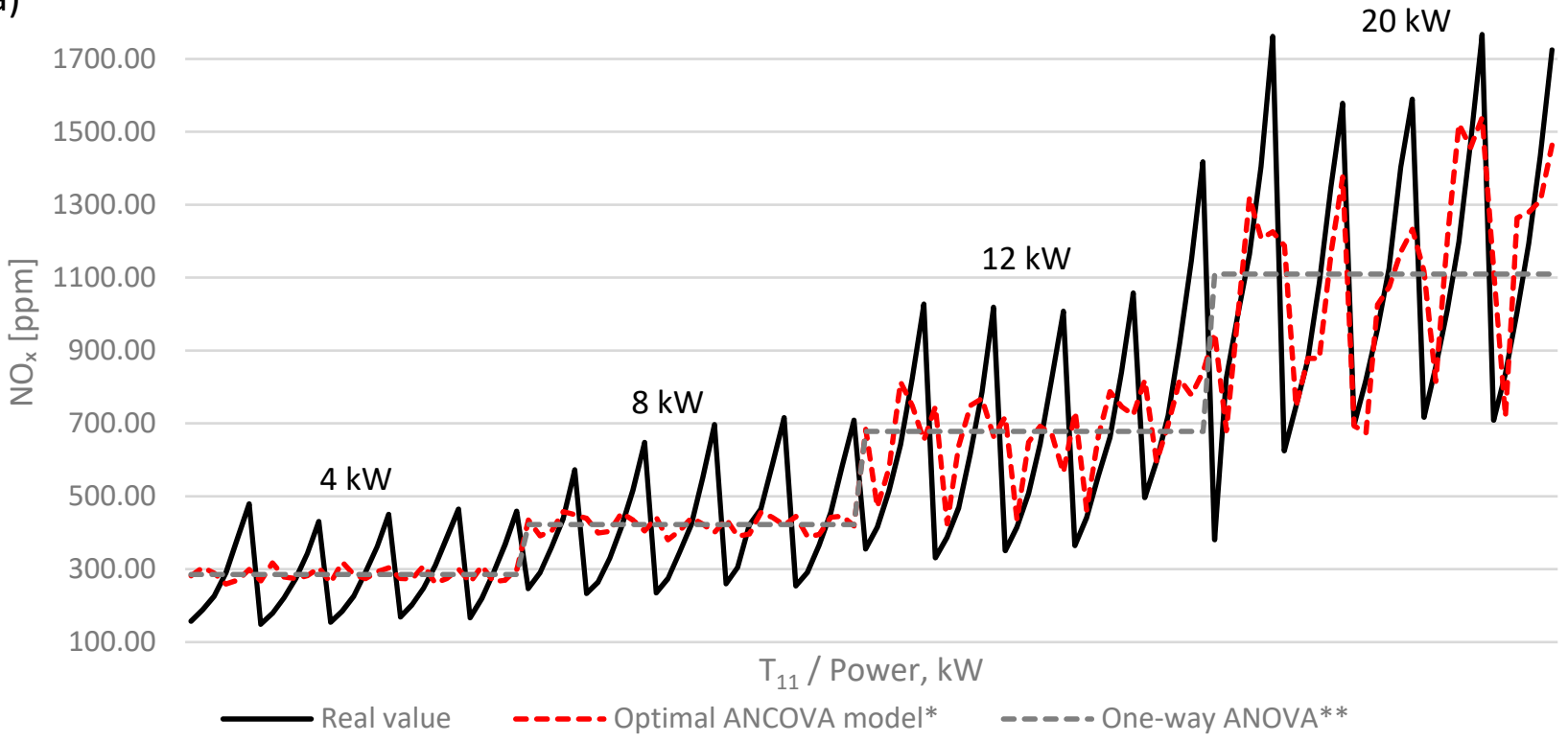

Figure 6. Cont. 


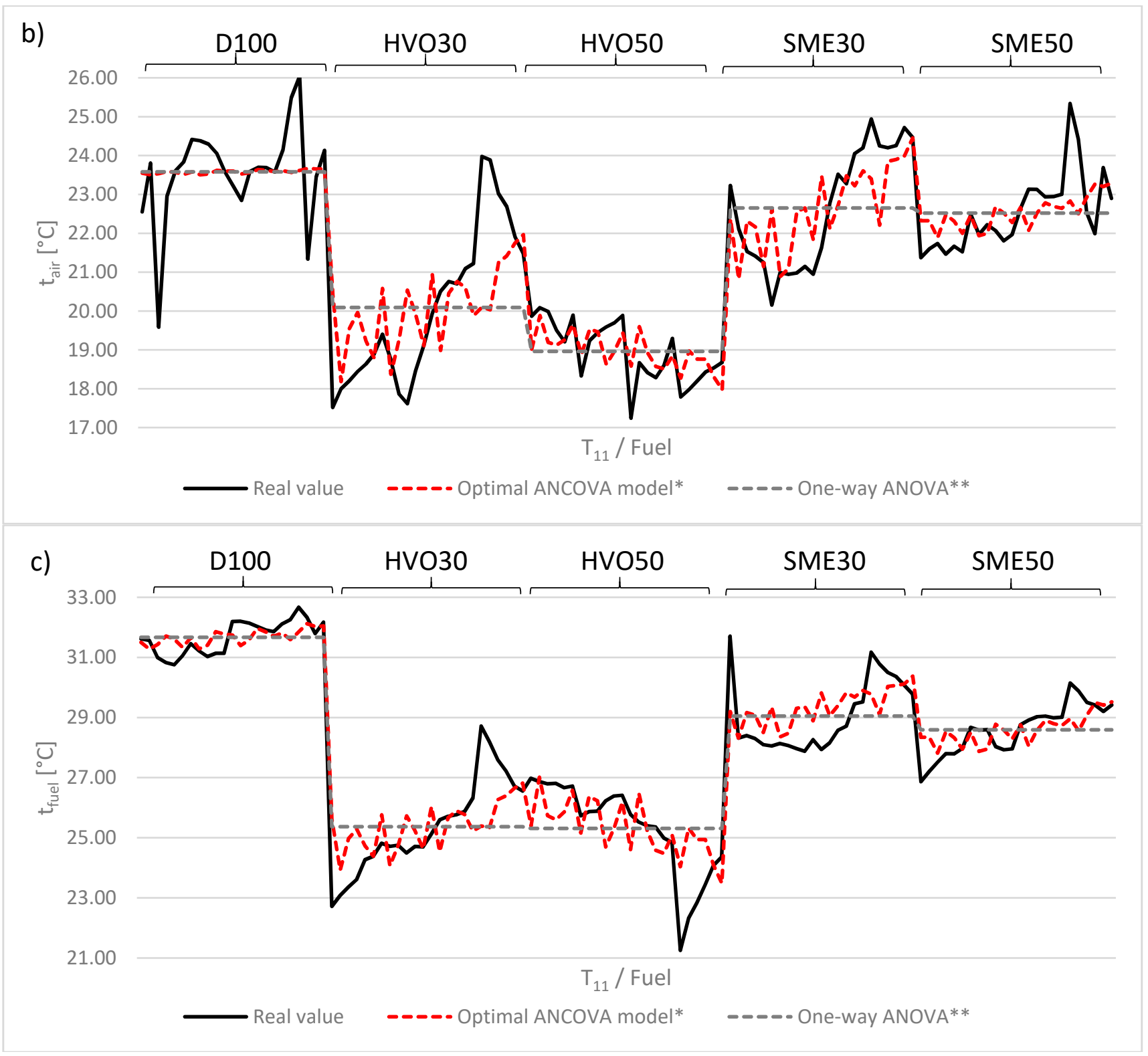

Figure 6. Engine exhausted emission real and prognostic values for (a) $\mathrm{NO}_{\mathrm{X}},(\mathbf{b}) \mathrm{t}_{\mathrm{air}}$ and (c) $\mathrm{t}_{\text {fuel }}$. Optimal ANCOVA model prognosis was made form Equation (2) and Table 8 parameter estimates. One-way ANOVA prognosis was made form one-way ANOVA with only power or type of fuel predictor.

\section{Conclusions}

Experimental data showed that engine power has the biggest influence on generated vibrational and sound pressure. Root mean square (RMS) values increased $20-30 \%$ while engine power was changed from $4 \mathrm{~kW}$ to $20 \mathrm{~kW}$ (data not shown). Type of fuel and injection timing was not associated with significant RMS differences (data not shown).

Vibration and sound pressure data have shown a high predictive power for exhausted emissions in univariate LRM analysis. All non-negative time domain statistics were associated with larger number of exhausted emissions which can be predicted using only vibration and sound pressure data. Furthermore, best predictor was defined RMS related function $T_{11}$. Vibration data gathered from TRAV ${ }_{1}$ and aggregated with $T_{11}$ had statistically significant impact for all 11 exhausted emission parameters.

ANOVA analysis revealed that engine power and type of fuel can be used in exhausted emissions prognostic equation development. In our case engine power was strong predictor 
for fuel mass flow, $\mathrm{CO}, \mathrm{CO}_{2}, \mathrm{NO}_{\mathrm{x}}, \mathrm{THC}, \mathrm{CO}_{\mathrm{Sick}}, \mathrm{O}_{2}$, air mass flow, $\mathrm{t}_{\text {exhaust }}$, whereas type of fuel was only a predictor of $t_{\text {air }}$ and $t_{\text {fuel }}$.

Consolidation of univariate LRM and ANOVA analyses shown increased prediction power for all 11 exhausted emission parameters. MAPE value reduced approximately three times from univariate LRM MAPE value. Prediction accuracy has grown in higher engine power modes by adding vibration data as a covariate variable in ANCOVA model while prediction remained independent from vibration data in lower engine power $(4 \mathrm{~kW}$ and $8 \mathrm{~kW}$ ). The same tendency was seen in different type of fuel. Prediction of exhausted emission parameters has grown in fuels HVO30, HVO50, SME30 and SME50 by adding vibration data as a covariate variable in ANCOVA model while prediction remained independent from vibration data in fuel D100.

Study findings conclude that adding vibration parameter to prognostic model helps to achieve higher prediction accuracy rate for various biodiesel fuels exhausted emissions in a regression model. The findings of the study allow concluding that adding vibration parameter to prognostic model helps to achieve higher prediction accuracy rate for various biodiesel fuel exhaust emissions in the regression model. Characteristics of noise and vibrations of diesel engines running on alternative fuels show reliable relationships with performance characteristics of the engine, volumes, and characteristics of emissions. Thus, the results received allow creating a reliable and inexpensive method for assessing the impact of various alternative fuel blends on important parameters of diesel engines.

Author Contributions: Conceptualization, T.Ž., J.M. and A.K.; methodology, T.Ž., D.V., J.M., K.K., A.R., Á.B., K.L. and A.K.; software, T.Ž.; validation, J.M., A.R. and A.K.; formal analysis, T.Ž.; investigation, T.Ž., J.M., A.R., Á.B. and A.K.; resources, Á.B. and K.L.; data curation, T.Ž., J.M., Á.B., K.L. and A.K.; writing—original draft preparation, T.Ž.; writing—review and editing, T.Ž., J.M., A.R., Á.B. and A.K.; visualization, T.Ž., J.M., A.R., Á.B. and A.K.; supervision, A.K.; project administration, A.K.; funding acquisition, A.K. All authors have read and agreed to the published version of the manuscript.

Funding: The research reported in this paper and carried out at the Budapest University of Technology and Economics has been supported by the National Research Development and Innovation Fund (TKP2020 National Challenges Subprogram, Grant No. BME-NCS) based on the charter of bolster issued by the National Research Development and Innovation Office under the auspices of the Ministry for Innovation and Technology.

Institutional Review Board Statement: Not applicable.

Informed Consent Statement: Not applicable.

Data Availability Statement: Not applicable.

Conflicts of Interest: The authors declare no conflict of interest.

\section{Nomenclature}

LHV Lower Heating Value (MJ/kg)

$n \quad$ Rotational speed of the crankshaft (rpm)

$\mathrm{t}_{\text {exhaust }}$ Exhaaust gas temperature $\left({ }^{\circ} \mathrm{C}\right)$

$\mathrm{t}_{\text {air }} \quad$ Intake air temperature $\left({ }^{\circ} \mathrm{C}\right)$

$\mathrm{t}_{\text {fuel }} \quad$ Fuel temperature $\left({ }^{\circ} \mathrm{C}\right)$

\section{Abbreviations}

ATDC

ANCOVA

ANN

ANOVA

ARF
After Top Dead Centre

Analysis of covariance

Artificial neural network

Analysis of variance

Air-fuel ratio 


\begin{tabular}{|c|c|}
\hline AVL & Anstalt für Verbrennungskraftmaschinen List \\
\hline ASTM & American Society for Testing and Materials \\
\hline BTDC & Before Top Dead Centre \\
\hline CAD & Crank Angle Degree \\
\hline CCLD & Signal Conditioners and Amplifiers \\
\hline $\mathrm{Ce}\left(\mathrm{CH}_{3} \mathrm{CO}_{2}\right)_{3} \cdot \mathrm{H}_{2} \mathrm{O}$ & Cerium (III) acetate hydrate \\
\hline CFPP & Cold Filter Plugging Point \\
\hline $\mathrm{CO}$ & Carbon monoxide \\
\hline CO Sick & Carbon monoxide measured by SICK Maihak S-710 \\
\hline $\mathrm{CO}_{2}$ & Carbon dioxide \\
\hline D100 & $100 \%$ conventional diesel fuel \\
\hline DIN & Deutsches Institut für Normung \\
\hline DTiCuN100 & Diesel +50 ppm $\mathrm{TiO}_{2}+50 \mathrm{ppm} \mathrm{Cu}\left(\mathrm{NO}_{3}\right)_{2}$ \\
\hline DTiCeA100 & Diesel $+50 \mathrm{ppm} \mathrm{TiO} 2+50 \mathrm{ppm} \mathrm{Ce}\left(\mathrm{CH}_{3} \mathrm{CO}_{2}\right)_{3} \cdot \mathrm{H}_{2} \mathrm{O}$ \\
\hline EGR & Exhaust Gas Recirculation \\
\hline EN & European Standards \\
\hline $\mathrm{HHO}$ & Hydroxy gas \\
\hline $\mathrm{HVO}$ & Hydrotreated Vegetable Oil \\
\hline HVO30 & $30 \% \mathrm{HVO}$ and $70 \% \mathrm{D} 100$ \\
\hline HVO50 & $50 \% \mathrm{HVO}$ and $50 \%$ D100 \\
\hline IC & Internal combustion \\
\hline ISO & International Organization for Standardization \\
\hline PC & Personal computer \\
\hline THC & Total Hydrocarbons \\
\hline $\mathrm{NO}_{\mathrm{x}}$ & Nitrogen oxides \\
\hline $\mathrm{O}_{2}$ & Oxygen \\
\hline LONG & Longitudinal \\
\hline LRM & Linear regression model \\
\hline MAPE & Mean absolute percentage error \\
\hline SD & Standart deviation \\
\hline SME & Soybean oil methyl ester \\
\hline SME30 & $30 \%$ SME and $70 \%$ D100 \\
\hline SME50 & $50 \%$ SME and 50\% D100 \\
\hline SP & Sound pressure \\
\hline $\mathrm{TiO}_{2}$ & Titanium (IV) dioxide \\
\hline TRAV & Traverse \\
\hline WCO & Waste cooking oil \\
\hline
\end{tabular}

\section{Appendix A}

Typical results of measurement of vibrations and sound pressure (D100, HVO50 and SME50) under $20 \mathrm{Nm}$ load and injection timing 10 CAD BTDC, respectively, marking: red -1 point transverse direction; blue -1 point longitudinal direction; green -2 points transverse direction; orange -2 points longitudinal direction; orange-sound pressure, please see Figure A1.

\begin{tabular}{|c|c|c|}
\hline D100 & HVO50 & SME50 \\
\hline 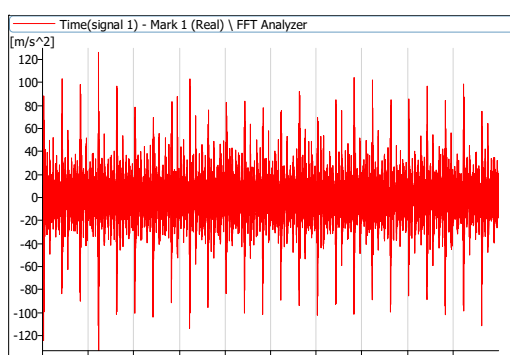 & 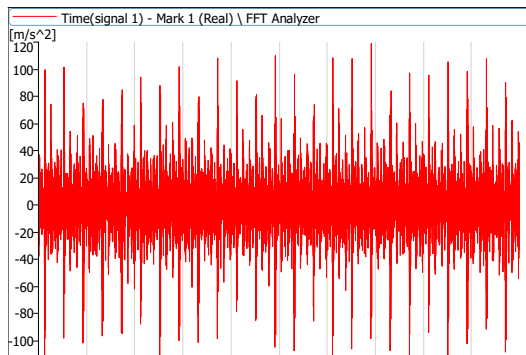 & 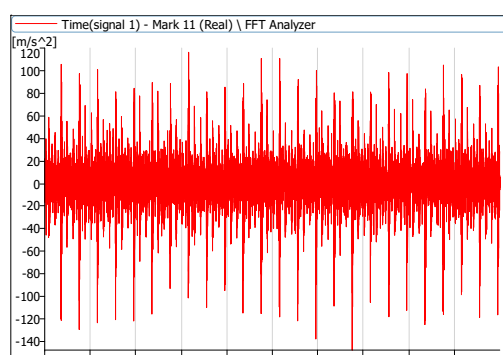 \\
\hline 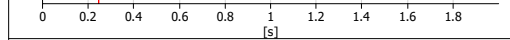 & $\begin{array}{llllllllll}0 & 0.2 & 0.4 & 0.6 & 0.8 & 1 & 1.2 & 1.4 & 1.6 & 1.8\end{array}$ & $\begin{array}{cccccccccc}0 & 0.2 & 0.4 & 0.6 & 0.8 & \frac{1}{[5]} & 1.2 & 1.4 & 1.6 & 1.8\end{array}$ \\
\hline
\end{tabular}

Figure A1. Cont. 


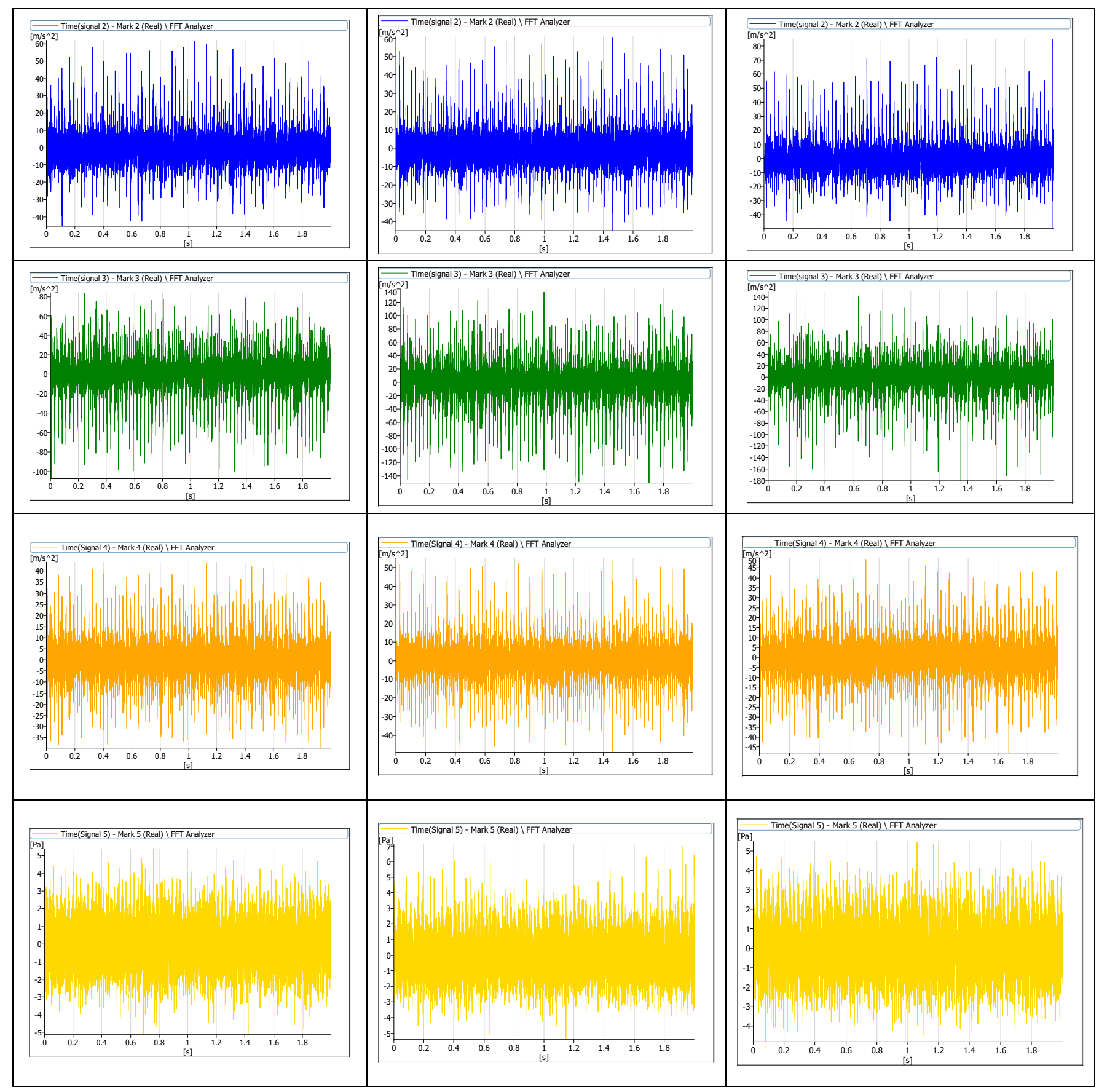

Figure A1. Typical results of measurement of vibrations and sound pressure (D100, HVO50 and SME50) under 20 Nm load and injection timing 10 CAD BTDC.

\section{References}

1. Sładkowski, A. (Ed.) Ecology in Transport: Problems and Solutions; Lecture Notes in Networks and Systems; Springer International Publishing: Cham, Switzerland, 2020; Volume 124, ISBN 978-3-030-42322-3.

2. Haasz, T.; Gómez Vilchez, J.J.; Kunze, R.; Deane, P.; Fraboulet, D.; Fahl, U.; Mulholland, E. Perspectives on decarbonizing the transport sector in the EU-28. Energy Strategy Rev. 2018, 20, 124-132. [CrossRef]

3. Fuc, P.; Lijewski, P.; Kurczewski, P.; Ziolkowski, A.; Dobrzynski, M. The analysis of fuel consumption and exhaust emissions from forklifts fueled by diesel fuel and liquefied petroleum gas (LPG) obtained under real driving conditions. In Proceedings of the Asme International Mechanical Engineering Congress and Exposition, Tampa, FL, USA, 3-9 November 2017.

4. Arthanarisamy, M.; Alagumalai, A.; Natarajan, N. Biodiesel as an Alternative Transportation Fuel in Diesel Engines An in-Depth Study on Biodiesel Performance; LAP LAMBERT Academic Publishing: Saarbrücken, Germany, 2016; ISBN 978-3-330-01535-7. 
5. Saravanan, P.; Kumar, N.M.; Ettappan, M.; Dhanagopal, R.; Vishnupriyan, J. Effect of exhaust gas re-circulation on performance, emission and combustion characteristics of ethanol-fueled diesel engine. Case Stud. Therm. Eng. 2020, 20, 100643. [CrossRef]

6. $\quad$ EL-Seesy, A.I.; Kayatas, Z.; Takayama, R.; He, Z.; Kandasamy, S.; Kosaka, H. Combustion and emission characteristics of RCEM and common rail diesel engine working with diesel fuel and ethanol/hydrous ethanol injected in the intake and exhaust port: Assessment and comparison. Energy Convers. Manag. 2020, 205, 112453. [CrossRef]

7. Zöldy, M. Ethanol-biodiesel-diesel blends as a diesel extender option on compression ignition engines. Transport 2011, 26, 303-309. [CrossRef]

8. Jamrozik, A.; Tutak, W.; Pyrc, M.; Gruca, M.; Kočiško, M. Study on co-combustion of diesel fuel with oxygenated alcohols in a compression ignition dual-fuel engine. Fuel 2018, 221, 329-345. [CrossRef]

9. Mirhashemi, F.S.; Sadrnia, H. NOX emissions of compression ignition engines fueled with various biodiesel blends: A review. J. Energy Inst. 2020, 93, 129-151. [CrossRef]

10. Sevinc, H.; Hazar, H. Investigation of performance and exhaust emissions of a chromium oxide coated diesel engine fueled with dibutyl maleate mixtures by experimental and ANN technique. Fuel 2020, 278, 118338. [CrossRef]

11. Raghuvaran, S.; Ashok, B.; Veluchamy, B.; Ganesh, N. Evaluation of performance and exhaust emission of C.I diesel engine fuel with palm oil biodiesel using an artificial neural network. Mater. Today Proc. 2020. [CrossRef]

12. Banković-Ilić, I.B.; Stojković, I.J.; Stamenković, O.S.; Veljkovic, V.B.; Hung, Y.-T. Waste animal fats as feedstocks for biodiesel production. Renew. Sustain. Energy Rev. 2014, 32, 238-254. [CrossRef]

13. Rimkus, A.; Matijošius, J.; Manoj Rayapureddy, S. Research of Energy and Ecological Indicators of a Compression Ignition Engine Fuelled with Diesel, Biodiesel (RME-Based) and Isopropanol Fuel Blends. Energies 2020, 13, 2398. [CrossRef]

14. Aatola, H.; Larmi, M.; Sarjovaara, T.; Mikkonen, S. Hydrotreated Vegetable Oil (HVO) as a Renewable Diesel Fuel: Trade-off between NOx, Particulate Emission, and Fuel Consumption of a Heavy Duty Engine. SAE Int. J. Engines 2008, 1, $1251-1262$. [CrossRef]

15. Zöldy, M. Fuel Properties of Butanol-Hydrogenated Vegetable Oil Blends as a Diesel Extender Option for Internal Combustion Engines. Period. Polytech. Chem. Eng. 2019, 64, 205-212. [CrossRef]

16. Dimitriadis, A.; Seljak, T.; Vihar, R.; Žvar Baškovič, U.; Dimaratos, A.; Bezergianni, S.; Samaras, Z.; Katrašnik, T. Improving PM-NOx trade-off with paraffinic fuels: A study towards diesel engine optimization with HVO. Fuel 2020, 265, 116921. [CrossRef]

17. Dobrzyńska, E.; Szewczyńska, M.; Pośniak, M.; Szczotka, A.; Puchałka, B.; Woodburn, J. Exhaust emissions from diesel engines fueled by different blends with the addition of nanomodifiers and hydrotreated vegetable oil HVO. Environ. Pollut. 2020, 259, 113772. [CrossRef] [PubMed]

18. Hunicz, J.; Matijošius, J.; Rimkus, A.; Kilikevičius, A.; Kordos, P.; Mikulski, M. Efficient hydrotreated vegetable oil combustion under partially premixed conditions with heavy exhaust gas recirculation. Fuel 2020, 268, 117350. [CrossRef]

19. Romig, C.; Spataru, A. Emissions and engine performance from blends of soya and canola methyl esters with ARB \#2 diesel in a DDC 6V92TA MUI engine. Bioresour. Technol. 1996, 56, 25-34. [CrossRef]

20. San José Alonso, J.; López Sastre, J.A.; Romero-Ávila, C.; López, E. A note on the combustion of blends of diesel and soya, sunflower and rapeseed vegetable oils in a light boiler. Biomass Bioenergy 2008, 32, 880-886. [CrossRef]

21. Omar, F.K.; Selim, M.Y.E.; Emam, S.A. Time and frequency analyses of dual-fuel engine block vibration. Fuel 2017, 203, 884-893. [CrossRef]

22. Yaşar, A.; Keskin, A.; Yıldızhan, Ş.; Uludamar, E. Emission and vibration analysis of diesel engine fuelled diesel fuel containing metallic based nanoparticles. Fuel 2019, 239, 1224-1230. [CrossRef]

23. Çalık, A. Determination of vibration characteristics of a compression ignition engine operated by hydrogen enriched diesel and biodiesel fuels. Fuel 2018, 230, 355-358. [CrossRef]

24. Nag, S.; Sharma, P.; Gupta, A.; Dhar, A. Combustion, vibration and noise analysis of hydrogen-diesel dual fuelled engine. Fuel 2019, 241, 488-494. [CrossRef]

25. Ong, Z.C.; Mohd Mishani, M.B.; Chong, W.T.; Soon, R.S.; Ong, H.C.; Ismail, Z. Identification of optimum Calophyllum inophyllum bio-fuel blend in diesel engine using advanced vibration analysis technique. Renew. Energy 2017, 109, 295-304. [CrossRef]

26. Uludamar, E.; Tosun, E.; Tüccar, G.; Yıldızhan, S..; Çalık, A.; Yıldırım, S.; Serin, H.; Özcanlı, M. Evaluation of vibration characteristics of a hydroxyl (HHO) gas generator installed diesel engine fuelled with different diesel-biodiesel blends. Int. J. Hydrog. Energy 2017, 42, 23352-23360. [CrossRef]

27. Uludamar, E.; Tosun, E.; Aydın, K. Experimental and regression analysis of noise and vibration of a compression ignition engine fuelled with various biodiesels. Fuel 2016, 177, 326-333. [CrossRef]

28. Taghizadeh-Alisaraei, A.; Ghobadian, B.; Tavakoli-Hashjin, T.; Mohtasebi, S.S. Vibration analysis of a diesel engine using biodiesel and petrodiesel fuel blends. Fuel 2012, 102, 414-422. [CrossRef]

29. Çelebi, K.; Uludamar, E.; Tosun, E.; Yıldızhan, Ş.; Aydın, K.; Özcanlı, M. Experimental and artificial neural network approach of noise and vibration characteristic of an unmodified diesel engine fuelled with conventional diesel, and biodiesel blends with natural gas addition. Fuel 2017, 197, 159-173. [CrossRef]

30. Çay, Y.; Korkmaz, I.; Çiçek, A.; Kara, F. Prediction of engine performance and exhaust emissions for gasoline and methanol using artificial neural network. Energy 2013, 50, 177-186. [CrossRef] 
31. Hosseini, S.H.; Taghizadeh-Alisaraei, A.; Ghobadian, B.; Abbaszadeh-Mayvan, A. Artificial neural network modeling of performance, emission, and vibration of a $\mathrm{CI}$ engine using alumina nano-catalyst added to diesel-biodiesel blends. Renew. Energy 2020, 149, 951-961. [CrossRef]

32. Koder, A.; Schwanzer, P.; Zacherl, F.; Rabl, H.-P.; Mayer, W.; Gruber, G.; Dotzer, T. Combustion and emission characteristics of a 2.2L common-rail diesel engine fueled with jatropha oil, soybean oil, and diesel fuel at various EGR-rates. Fuel 2018, $228,23-29$. [CrossRef]

33. Zhang, Z.; Liu, X.; Liu, H.; Wu, Y.; Zaman, M.; Geng, Z.; Jin, C.; Zheng, Z.; Yue, Z.; Yao, M. Effect of soybean oil/PODE/ethanol blends on combustion and emissions on a heavy-duty diesel engine. Fuel 2021, 288, 119625. [CrossRef]

34. Rimkus, A.; Žaglinskis, J.; Rapalis, P.; Skačkauskas, P. Research on the combustion, energy and emission parameters of diesel fuel and a biomass-to-liquid (BTL) fuel blend in a compression-ignition engine. Energy Convers. Manag. 2015, 106, 1109-1117. [CrossRef]

35. Rimkus, A.; Stravinskas, S.; Matijošius, J. Comparative Study on the Energetic and Ecologic Parameters of Dual Fuels (Diesel-NG and HVO-Biogas) and Conventional Diesel Fuel in a CI Engine. Appl. Sci. 2020, 10, 359. [CrossRef] 